\title{
The Role of Debt and Dependency in Shaping West Virginia's Political Economy, 1820-1920
}

Chad R. Holmes

Follow this and additional works at: https://researchrepository.wvu.edu/etd

\section{Recommended Citation}

Holmes, Chad R., "The Role of Debt and Dependency in Shaping West Virginia's Political Economy, 1820-1920" (2016). Graduate Theses, Dissertations, and Problem Reports. 7091.

https://researchrepository.wvu.edu/etd/7091

This Thesis is protected by copyright and/or related rights. It has been brought to you by the The Research Repository @ WVU with permission from the rights-holder(s). You are free to use this Thesis in any way that is permitted by the copyright and related rights legislation that applies to your use. For other uses you must obtain permission from the rights-holder(s) directly, unless additional rights are indicated by a Creative Commons license in the record and/ or on the work itself. This Thesis has been accepted for inclusion in WVU Graduate Theses, Dissertations, and Problem Reports collection by an authorized administrator of The Research Repository @ WVU. For more information, please contact researchrepository@mail.wvu.edu. 
The Role of Debt and Dependency in Shaping West Virginia’s Political Economy, 1820-1920

Chad R. Holmes

Thesis submitted to the Eberly College of Arts and Sciences at West Virginia University

In partial fulfillment of the requirements for the degree of

Master of Arts in History

Brian Luskey, Ph.D., Chair

Jason Phillips, Ph.D.

Kim Welch, Ph.D.

Department of History

Morgantown, West Virginia

2016

Keywords: Political Economy, Antebellum, Debt, Dependency, Civil War, Statehood, Internal Improvements Copyright 2016 Chad Holmes 


\begin{abstract}
The Role of Debt and Dependency in Shaping West Virginia’s Political Economy, 1820-1920
\end{abstract}

\author{
Chad R. Holmes
}

This thesis evaluates how West Virginia's perceptions of debt and dependency were formed and contributed to the state's political economy throughout the nineteenth century. As a part of the Virginia Commonwealth, western Virginians used antebellum political debates to independently control regional resources and seize the political prestige of connecting the nation's east to the nation's west. When eastern Virginians seceded from the Union in 1861, western Virginians saw an opportunity to claim their independence. Secessionist and unionist support provided the political chaos necessary for western Virginians to declare their independence. Political uprisings sprouted up throughout western Virginia. Northwestern Virginia's pro-Union leaders vowed to support northern efforts. The addition of western Virginia to the Union provided President Lincoln with an important war measure to weaken the Commonwealth and contribute to a pressing demand for troops and resources. However, before western Virginians could seize their independence, they were asked to reconcile a debt. Virginia's antebellum investments, which western Virginia supported to varying degrees, generated an unresolved public debt of over \$30 million at the start of the Civil War. Prior to and after achieving statehood, western Virginians engaged in political debates over the public debt and how it should be addressed.

Perceptions of debt were both deeply political in the nineteenth century and contributed to the formation of West Virginia's political economy. West Virginians engaged in debates over investment and capital that collided with concerns over lost reputation and dependence. This thesis is organized into three chapters that evaluate how public debt emerged as a central factor that influenced political perspectives in West Virginia from 1820 to 1920. Antebellum political debates over banking policies, internal improvements and the justice system shaped western perceptions over public investment and financial obligations. During the Civil War and the march towards statehood, West Virginians shifted their processes for accumulating, acknowledging, and reconciling debt issues. West Virginia shifted its dependent relationship to the federal government and northern investors interested in a Union victory. Postbellum debates over resolving antebellum and wartime debts led to a prolonged dispute among the former Commonwealth factions and debates over how the outstanding debt should be resolved. The dispute was finally resolved through the intervention of the United States Supreme Court in the early twentieth century. West Virginia's failed legal arguments reaffirmed a political inferiority that provided a foundation for the state's postcolonial political economy throughout the nineteenth century and reflected the state's inherent dependence on other political bodies. 


\section{Table of Contents}

Introduction: An Activated Citizenry .......................................................................... 1

Chapter 1: Don’t Run Into Debt: Antebellum Debates over Public Investments and the Development of Virginia’s Public Debt

Chapter 2 : Who Is to Be Bound for This Debt?: Resolving Issues of Debt during the Civil War

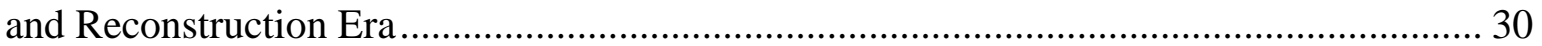

Chapter 3: Make No Deep Scrutiny Into Her Mutiny: The Supreme Court’s Rulings in the Commonwealth of Virginia v. The State of West Virginia ............................................... 50

Conclusion: A Fair and Equitable Proportion..................................................................... 73

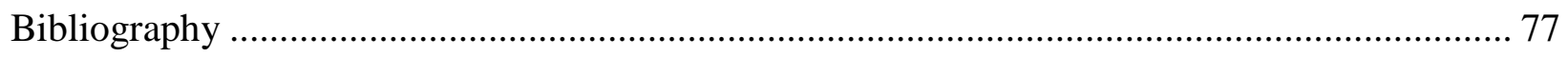




\section{Introduction: An Activated Citizenry}

This thesis evaluates how West Virginia’s perceptions of debt and dependency were formed and contributed to the state's political economy throughout the nineteenth century. As a part of the Virginia Commonwealth, western Virginians used antebellum political debates to independently control regional resources and seize the political prestige of connecting the nation's east to the nation's west. When eastern Virginians seceded from the Union in 1861, western Virginians saw an opportunity to claim their independence. Secessionist and unionist support provided the political chaos necessary for western Virginians to declare their independence. Political uprisings sprouted up throughout western Virginia. Northwestern Virginia’s pro-Union leaders vowed to support northern efforts. The addition of western Virginia to the Union provided President Lincoln with an important war measure to weaken the Commonwealth and contribute to a pressing demand for troops and resources. However, before western Virginians could seize their independence, they were asked to reconcile a debt. Virginia’s antebellum investments, which western Virginia supported to varying degrees, generated an unresolved public debt of over \$30 million at the start of the Civil War. Prior to and after achieving statehood, western Virginians engaged in political debates over the public debt and how it should be addressed.

Perceptions of debt were both deeply political in the nineteenth century and contributed to the formation of West Virginia’s political economy. West Virginians engaged in debates over investment and capital that collided with concerns over lost reputation and dependence. This thesis is organized into three chapters to evaluate how public debt emerged as a central factor that influenced political perspectives in West Virginia from 1820 to 1920. Chapter One evaluates how debt perspectives shaped debates over banking policies, internal improvements and the justice system. State constitutional conventions, regional newspapers, and county lawsuits reflect disputes over western 
Virginian political and economic reforms. Chapter Two evaluates West Virginia's processes for accumulating, acknowledging, and reconciling debt issues during the Civil War era. The development of a proxy eastern Virginia government, i.e. the "Restored State of Virginia", executed questionable interstate agreements over debt agreements and political reforms that led to the creation of West Virginia. These agreements created a precarious scenario for West Virginia in which the debts and statehood became contingent on the outcome of the war itself. West Virginia shifted its dependent relationship to the federal government and northern investors interested in a successful Union victory. Speeches, constitutional conventions, and congressional testimony depict the irony of West Virginia becoming independent from Virginia and in the process becoming dependent on the federal government. Chapter Three addresses the competing political positions used during the resolution of the debt controversy through the Supreme Court. This chapter reviews Virginia's legislative reforms and debt commission actions that led to the Commonwealth's 1906 Supreme Court filing. The Supreme Court's decision represented a mandate on West Virginia’s rights to manage and administer a political economy with the intervention of another political body. West Virginia's loss in the Supreme Court case reaffirmed a political inferiority that provided a foundation for West Virginia’s postcolonial political economy throughout the nineteenth century and reflected the state's inherent dependence on others to drive its political economy.

Focusing on the political nature of debt contributes to the existing historiography of the United States' nineteenth-century political economy. Western Virginians formulated their political identities and shaped their political economy through debates over debt and dependency. Recent historiography of Virginia's antebellum political economy focuses on economic modernization. In his 2013 dissertation, George Gilliam argued that Virginia’s public institutions became essential to rebuilding a postbellum economy gradually throughout the nineteenth century. Gilliam contends that 
“The process by which Virginians rebuilt their public and private institutions, renewed and strengthened ties with the national economy, and reconstructed the Old Dominion's political and economic infrastructure, was a gradual one, pushed and pulled by forces that were evident in the state decades before the Civil War.” ${ }^{1}$ Gilliam focused on the adaptability of Virginia’s political, economic, and judicial institutions. However, he fails to acknowledge how regionally defined perceptions of debt and dependency shaped eastern and western Virginia’s sectional crises that led to western secession during the Civil War.

The recent historiography of nineteenth-century debt and dependency addressed the sociopolitical perceptions of financial failure, availability of capital and credit in encouraging excessive consumption, and the role that race played in shaping perceptions of debt. Historians Bruce Mann and David Silkenat evaluated how debt and dependency emerged as key byproducts of the economy. Mann asserts that Americans adopted a commercial culture rife with financial speculation, leading to increased levels of personal indebtedness and insolvency during the Early Republic. Americans actively used credit to invest in new and unpredictable economic markets, which created the potential for economic success and failure. ${ }^{2}$ By contrast, Silkenat depicts how white and black North Carolinians held considerably different opinions of bankruptcy protection, the use of credit, and secondary market economies (such as pawnshops and boardinghouses). ${ }^{3}$ These differences substantiated Silkenat's overall evaluation of black and white North Carolinians' reactions to being in debt. Mann's and Silkenat's work contribute to our understanding of the impact of indebtedness on the political and social spheres of the American political economy during the nineteenth century.

\footnotetext{
${ }^{1}$ George Harrison Gilliam, "Building a Modern South: Political Economy in Nineteenth Century Virginia” (Doctoral Dissertation) University of Virginia, Charlottesville, 2013, (No. AAT 3570386), Abstract, ii.

${ }^{2}$ Bruce H. Mann, Republic of Debtors: Bankruptcy in the Age of American Independence (Cambridge: Harvard University Press, 2002).

${ }^{3}$ David Silkenat, Moments of Despair: Suicide, Divorce, and Debt in Civil War Era North Carolina (Chapel Hill: University of North Carolina Press, 2011).
} 
Focusing more specifically on the integration of economic failure into society, historians Edward Balleisen and Scott Sandage addressed how Americans adapted to bankruptcy as a byproduct of the nation's industrialization and commercial growth. Balleisen argued that the Bankruptcy Protection Act of 1841 reflected a shift in how the national legislature viewed financial failure. Congress recognized the importance of voluntary bankruptcy in administering issues of indebtedness. Individual insolvency emerged as a nationwide issue that touched on all aspects of American society, including the political system. ${ }^{4}$ Similarly, Sandage focused on the role of insolvency and financial failure in shaping identities throughout the nineteenth century. Sandage asserts that "Besides marking particular reversals of fortune, [Americans] perceived that failure measured a man's ambition and approach to life. In a culture defined by 'the tug of business,' failure was no longer just an affliction; it was fast becoming an identity." ${ }^{5}$ The analysis presented in this thesis complements this historiographical analysis by linking cultural and political perspectives of debt to the formulation of the broader political economy. Public debt emerged as a means of shared commitment and oppressive control throughout the century. Acknowledging and refuting public debt became a matter of honor and reputation that pitted Virginia and West Virginia against one another for over a century and shaped the controversy after the Civil War ended.

Debt emerged as a central theme in the nation's political economy because of the rise in financial exchanges that challenged the balances of power. The advent of capital-generating policies and institutions fueled changes in how Americans generated financial commitments. Private credit agreements, public taxes, and long-term investments through public bonds created conflicts over perceptions of power dynamics. Americans confronted questions over public accountability and

\footnotetext{
${ }^{4}$ Edward Balleisen, Navigating Failure: Bankruptcy and Commercial Society in Antebellum America. (Chapel Hill: University of North Carolina Press, 2001), 167.

${ }^{5}$ Scott Sandage, Born Losers: A History of Failure in America (Cambridge: Harvard University Press, 2005), 16.
} 
redemption for poorly fabricated investments. These dynamics became critical when placed in the context of the nation's debates over secession and emancipation. This volatile political economy also redefined the nature of public investment and debt. Understanding debt and dependence as a matter of political positioning is necessary in order to understand why West Virginians sought financial control from the Commonwealth's Richmond leadership, agreed to pay a portion of Virginia’s public debt, and challenged federal authorities who demanded a debt resolution. Regional communities striving for public stability struggled to manage debts stemming from local needs (such as the administration of justice) with state needs (such as financing of internal improvements). These demands placed West Virginia’s priorities at odds with broader macroeconomic priorities.

Prior to the Civil War, western Virginians’ perspectives about debt conflicted with easterners’ perspectives because the latter centered on consolidation of the Commonwealth’s resources. Easterners controlled the state's political processes and only reluctantly acknowledged westerners as equals during the frequent political debates. Consequently, statewide reforms, when imposed at the local level, generated questions over government intervention in both creating and participating in lawsuits in issues of indebtedness that pitted eastern and western interests against each other. Economist Robert Kuttner's Debtor's Prison provides an important clarification to the potential risk. Kuttner argues, “In a capitalist society with extremes of inequality, it is only natural that owners or manipulators of vast pools of capital should [wield] political power. In a democracy, an activated citizenry can contest that dominance and channel finance to a role more conducive to broad prosperity... ."6 The political nature of debt is generated through disputes over the control of capital and the role of public institutions in managing and resolving debt feuds. Americans incurred debt through tax increases, internal improvement investments, and military deployments, which led

\footnotetext{
${ }^{6}$ Robert Kuttner, Debtors' Prison: The Politics of Austerity Versus Possibility (New York: Alfred A. Knopf, 2013), 11.
} 
to political disputes over power dynamics between competing political entities at the county, state, and national levels.

West Virginia's failed efforts to create political equality and separation reflected changes in the state's political economy throughout the nineteenth century. An underlying concern over political and economic inferiority was embedded in western Virginia during the antebellum period. Westerners fought perceptions that the region provided colonial resource support for the Commonwealth's eastern-led slave economy. The Civil War temporarily provided the new state of West Virginia with an opportunity to establish political, economic, and cultural independence. After decades of clashing with eastern Virginians over capital, investments, and justice, West Virginia sought a political economy based on the fair distribution of capital and political authority. West Virginia’s willingness to pay a “fair and equitable proportion” of another state’s debt was a political expression of sovereign control. However, independence and control were temporary. Throughout the remainder of the nineteenth century, West Virginia’s political economy reflected a transferal of dependence from Virginia to the United States government that reflected a continuation of the region's perception of providing only colonial support. West Virginia maintained a postcolonial political economy that held the new state in a "lingering colonial dependence — and a corresponding sense of inferiority” and a continued political interference by the federal government. ${ }^{7}$ West Virginians, struggling to become independent from Virginia, were unable to define their political identity as an independent state.

\footnotetext{
${ }^{7}$ Kariann Akemi Yokota, Unbecoming British: How Revolutionary America Became a Postcolonial Nation (Oxford: Oxford University Press, 2011), 11. I am adopting Yokota's argument - that Revolutionary America's incomplete efforts to create a separate and distinct political culture resulted in the persistence of a dependent political economy struggling for a distinct identity—as a means of examining how West Virginia created and struggled with the changing political and economic realities of the nineteenth century.
} 
Understanding how West Virginia's political economy transitioned from a position of "fair and equitable proportionality" to a position of "postcolonial dependence" is the focus of this thesis. 


\section{Chapter 1: Don't Run Into Debt: Antebellum Debates over Public Investments and the Development of Virginia's Public Debt}

During the forty years leading up to the Civil War, Congress debated strategies such as forming the Bank of the United States, creating a national infrastructure of public works expanding slavery to new states, and implementing a coherent internal improvement system in order to build a stronger political economy. Within Virginia, political representatives in the western part of the state politically positioned their region as the economic bridge linking the nation's east with the west. Their hopes of developing and maintaining commercial connectivity to both eastern Virginians and the greater Ohio River Valley shaped westerners’ political policies. Their perspectives on indebtedness significantly influenced the way citizens of western Virginia thought about political economy during the antebellum era. For instance, a Harrison County, Virginia newspaper, Cooper's Clarksburg Register, published the poem “Don’t Run in Debt” in a March 1852 edition. In support of the hard currency debate that unfolded after private bank failures of the 1840s, the poem proposed, “Good friends, let me beg you, don’t run in debt / If the chairs and sofas are old / They will fit your backs better than any new set / Unless they are paid for-with gold.”8 In short, the poem highlighted an existing dichotomy in the western Virginia economy: too much debt should be avoided unless it was debt that was properly financed. Understanding indebtedness provides a clearer insight into how Americans understood and responded to both local and national commitments generated by the rapidly changing political environment. Debt defined political commitments and influenced power shifts between local authorities, internal and external commercial interests, and federal power in the nineteenth century.

8 “Don’t Run In Debt”, Cooper's Clarksburg Register, Clarksburg, Virginia, March 10, 1852. 
Western Virginia’s perceptions of debt were deeply politicized and reflected emerging national debates during the antebellum era about financial obligations and commitments. Three factors shaped regional perceptions of debt. First, statewide banking reforms created regional tensions. Bankers and the bank-chartering processes exerted power over the way capital was distributed. Western Virginians' efforts to maintain regional industrial banks clashed with eastern Virginians' promotion of branch banking systems that allocated bank charters to regions based on political loyalties. Second, infrastructure development influenced community obligations and responsibilities. State spending priorities conflicted with regional priorities over where and how internal improvement programs should be deployed. The third factor, county courts and debt collection efforts, provided a public place for issues of debt to be settled among a wide array of debtors and creditors. Federal, state, and local plaintiffs filed suit against western Virginians and in the process, altered perceptions of financial commitments and indebtedness. Accepting and acknowledging certain forms of indebtedness—-while rejecting other forms—-became the price that western Virginians paid for their political identity and cohesiveness. These factors reflected the nation’s emerging debates over dependency, financial failure, and public intervention that erupted during the Civil War.

Prior to 1863, western Virginia was the Old Dominion's gateway to the west, a place shaped by easterners' commercial ambitions and westerners' concerns of being politically underrepresented. Throughout the nineteenth century, Virginia's leaders remained committed to linking eastern markets in Richmond to western resources through a cohesive transportation network of railroads and canals running to Wheeling and Parkersburg. Aspirations of equaling other states' success stories, such as New York's Erie Canal, were beset by political frustrations and financial failures. Political concerns about overburdening eastern plantation owners with increased taxes led Virginia’s leadership to rely 
more heavily on public bonds to finance a fragmented internal improvement plan. A deep political sectionalism emerged between eastern and western Virginians that created polemic debates over taxation, political representation, and internal improvement projects. Debt underlined these disputes. Western Virginians framed their political environment in terms of autonomy, self-reliance, and commercialization. Westerners in Brooke, Ohio, and Monongalia counties worried that accumulating commercial and public debt for investments that principally benefited easterners, such as the statebacked Virginia Central Railroad, would lead to their political subordination and dependence.

Economic control and political influence over western resources emerged as a key debate in the antebellum period. In 1820, the western economy exhibited signs of the nation's ever-changing social, political, and economic structures: transportation expansion, westward migration, and a growing reliance on banking to fund future growth. Ohio County, western Virginia’s largest region, grew in population from 4,700 residents in 1800 to over 18,000 by $1850 .{ }^{9}$ The city of Wheeling, both the regional commercial hub and the county seat for Ohio County, grew to be the $51^{\text {st }}$ largest town in the United States by $1840 .{ }^{10}$ Investors flocked to the region in hopes of profiting from the rapid commercial growth driven by the salt, iron, and glass industries in Ohio County. Growing disparities in population and industrial growth led many Virginians to assess the role westerners should have in driving the state's—and possibly, the nation's—political capabilities.

Through the constitutional convention of the 1820s, political leadership engaged in debates over key democratic reforms and rights. Eastern Virginians prioritized political stability and hereditary property rights as being central in their debates over political representation and public responsibilities. Richmond representative, Philip Nicholas, argued for political representation to be

\footnotetext{
${ }^{9}$ University of Virginia Geospatial and Statistical Data Center, Historical Census Browser, (accessed November 8, 2015), http://mapserver.lib.virginia.edu.

${ }^{10}$ United Status Bureau of the Census, Table 7: Population of the 100 Largest Cities: 1840, (accessed November 8, 2015), www.census.gov/population/www/documentation/twps0027/tab07.txt.
} 
linked to community commitment, which could be developed through a "lasting ownership of the soil of the country." ${ }^{11}$ Western reliance upon credit and temporary land ownership threatened the political balance of Virginia. Historian Christopher Curtis argued that this political tension emerged from the "reconceptualization of republic political ideals [based on] a more democratic belief that diverse forms of property ownership also possessed political value...."12 Eastern Virginians associated the ownership of real property and wealth with a person's ability to govern and rule. These perspectives clashed with westerners reliant upon credit to acquire land for short-term use. Lowerand middle-class westerners complicated representation debates through the acquisition of property with credit. Tenant farming and freeholding arrangements clashed with more traditional rights of slaveholding and agricultural plantations that easterners cited as necessary for political involvement. ${ }^{13}$

Through the convention, westerners attempted to combine the region's growing populations and diverse forms of property to gain greater political control. Brooke County representative, Phillip Doddridge, proposed a constitutional amendment changing how legislative representation could be assessed. Doddridge proposed a ten-year census to determine district representation levels throughout the state. ${ }^{14}$ Politically, easterners viewed the amendment as a challenge to the shared principles of Virginia's political economy. Charlotte County’s John Randolph objected to the amendment and chastised the west for destabilizing Virginia’s political framework: "Sir, I see no wisdom in making the provision for future changes. You must give Governments time to operate on the people, and give people time to become gradually assimilated to their institutions. Almost anything is better than this

\footnotetext{
${ }^{11}$ Virginia Constitutional Convention, Proceedings and Debates of the Virginia State Convention of 1829-1830, (New York: De Capo Press, 1971), 364.

${ }^{12}$ Christopher M. Curtis, "Reconsidering Suffrage Reform in the 1829-1830 Virginia Constitutional Convention," Journal of Southern History 74, no. 1 (February 2008): 90.

${ }^{13}$ Curtis, "Reconsidering Suffrage", 93.

${ }^{14}$ Virginia Constitutional Convention, Proceedings and Debates, 485.
} 
state of perpetual uncertainty.”"15 A western willingness to incur debt to acquire the requisite land, resources, and political control daunted eastern leadership. Randolph concluded, “The period has arrived of living by one's wits—of living by contracting debts that one cannot pay—and above all, of living by office hunting. Bankrupts—-branded bankrupts giving great dinners—sending their children to the most expensive schools_ — giving grand parties—and just as well received as anybody in society." ${ }^{16}$ Statewide political control—established through generational distributions of wealth and property — was threatened by a western willingness to gain property and social status through credit required to take part in the political processes. Debt provided westerners with a political instrument to gain greater influence and power. The growth of public sector institutions, such as county courts and banks, paralleled the growth in population and commercial sector. While western Virginians developed a persuasive case for both political and commercial autonomy from the rest of the Commonwealth, the infusion of state institutions undermined this independence.

State and regional political interests collided through the advancement of differing Commonwealth banking practices. The collateral used to support credit extensions provided the public with differing means for trading assets for credit: land banks accepted real estate, commercial banks accepted specie. ${ }^{17}$ Antebellum banks created, utilized, and administered networks of capitalgenerating and credit-needy individuals interested in shaping a community based on their shared perspective. The bank chartering processes promoted the public’s interests through political approaches that placed banks in regions where the banks could prosper and politicians could gain public recognition. The commercial objectives of regional bank promoters and state legislatures

\footnotetext{
${ }^{15}$ Virginia Constitutional Convention, Proceedings and Debates of the Virginia State Convention of 1829-1830 : To Which Are Subjoined the New Constitution of Virginia, and the Votes of the People (Richmond: Samuel Shepard and Company, 1830), 790.

${ }^{16}$ Virginia Constitutional Convention, Proceedings and Debates of the Virginia State Convention, 790-791.

${ }^{17}$ Brian Phillips Murphy, Building The Empire State: Political Economy in the Early Republic (Philadelphia: University of Pennsylvania Press, 2015), ix-X.
} 
converged through the chartering process that granted charters for the establishment of local banks.

As a result, "Banks, as organizations, were believed to harbor and act on the party sympathies of both their promoters and the legislative majority at the time the charter act was passed." ${ }^{18}$ Unlike local banks that leveraged the regional economy both to thrive and develop, state banks leveraged the political processes of the legislature and economic leadership to drive capital to areas where legislative objectives could be enhanced with state capital.

The Commonwealth’s increased reliance on state-owned banks and chartering processes both restrained western Virginians from developing their own financial obligations and shifted financial responsibility to eastern state authorities. Banking reflected the rapid merger of finance, politics, and power critical to the growth of the American West. Brian Murphy argues that banks reflected the perfect combination for the “economically and politically ambitious” proprietors interested in obtaining political and commercial success. Bankers maintained political influence through networks and commercial loyalties, including state governments. Murphy contends that "The act of granting and tapering access to the credit while excluding others ... is what gives bankers their power. Banks therefore shape their clients' interests, and if a bank is a lender to local or state governments, its directors calibrate the interests of those public entities as well.”19 The convergence of public institutions and banking formed political links between state interventions and financial commitments.

The chartering of the Bank of Virginia in 1804 established a consolidation of the state’s financial resources in Richmond and led to the convergence of banking and politics within the state. State leadership maintained several avenues for influencing bank operations. State leadership appointed all members on a ten-person Board of Directors and the State Treasurer influenced the

\footnotetext{
${ }^{18}$ Howard Bodenhorn, State Banking in the Early Republic (Oxford: Oxford University Press, 2003 ), 13.

${ }^{19}$ Murphy, Building the Empire State, 23-24.
} 
management of the Bank by holding a deciding vote on electing the Bank’s Board of Directors. These processes favored eastern control over the Bank of Virginia's actions and policies. Annual stock investments, funded through a combination of low-interest bank loans and taxes, allowed state leadership to create a strong political partnership with the Bank. Commerce expert George Starnes argued that the Bank's "complete monopoly, granted by the state and in which the state has an interest, is prone to feel that it can do as much as it pleases.” ${ }^{20}$ This control enabled eastern leadership to guide and restrict where banks could be established and how credit could be infused into a local economy. While the Commonwealth's leadership sought to develop banks in the western region, ownership of the bank's capital remained in eastern control.

Prior to 1818, westerners relied upon private banks to finance key projects and growth areas. Private banks evolved in tandem with the growth of salt, iron, and glass industries. These local private banks raised concerns that the wealth of the state would be diluted by these smaller enterprises. Virginia's legislature, determined to shut down private banks conflicting with statebacked institutions, passed legislation in 1816 closing the private banks. The Western Bank of Virginia, the Saline Company, the Ohio Company, and the Farmer's Mechanics’ and Merchants' Bank of Jefferson, suspended operations by August 31, 1818. The removal of the private banks minimized competition with the Commonwealth's Bank of Virginia. However, the removal of the private banks did little to infuse greater capital into the western Virginian region. Political concerns were raised that the series of small banks would minimize the control that the state leadership held over the banks' investments and management. ${ }^{21}$ Virginia’s legislature established new statechartered banks in Wheeling between 1818 and 1834: the Northwestern Bank of Virginia (NWVA) and Merchants' and Mechanics' Bank of Wheeling (MMB). These institutions provided westerners

\footnotetext{
${ }^{20}$ George T. Starnes, Sixty Years of Branch Banking in Virginia (New York: Macmillan Company, 1931), 34-39.

${ }^{21}$ Starnes, Sixty Years, 60-63.
} 
with financial institutions to fund ongoing internal improvement projects in the region throughout the rest of the antebellum period.

Government intervention through the banking sector influenced ways in which western Virginians acquired capital and controlled their own debt. Western Virginia’s autonomy was undermined by the involvement of the state government in minimizing western control over the banks and reducing the region’s overarching investment capabilities. Government interference throughout the antebellum era led to unacceptably large financial commitments that western Virginians did not actually generate. After decades of government interference, the Wheeling Intelligencer encouraged citizens to consider the political implications of continuing to allow stateowned institutions to drive bank circulation when "our debt and taxes are already high.” Instead, the western economy should be able to administer its own bank notes because "The amount of bank note circulation in any particular region should be limited and controlled by the necessities of the business of that region."22 While the North Western Bank of Virginia and the Merchants' and Mechanics' Bank provided banking institutions to serve Wheeling and their neighboring cities, the banks were relatively small compared to the rest of the state-owned banks. Individually, these two banks represented Virginia's smallest state-owned banks.

Western Virginians sought to have regionally owned banks as a means of controlling capital and minimizing overall debt. Western Virginia's regional community was built on the potentially vast commercial network within the Ohio River Valley. It spanned northward to Pittsburgh, Pennsylvania and Zanesville, Ohio, as far west as Vincennes, Indiana and as far south as Nashville, Tennessee. This was central to their identity. ${ }^{23}$ Regional communities understood both their rates of

\footnotetext{
22 "Banks and Banking” Wheeling Intelligencer, (Wheeling, West Virginia), October 19, 1855.

${ }^{23}$ Kim M. Gruenwald, River of Enterprise: The Commercial Origins of Regional Identity in the Ohio Valley, 17901850 (Bloomington: Indiana University Press, 2002), 40-41.
} 
consumption and how investments could achieve the targeted profitability. Historian Kim Gruenwald linked the debates over fiscal influence and control as a central point of contention between the broader Ohio River Valley region and eastern authorities: "Many Ohio River Valley residents ... found their western identity in confronting eastern politicians and bankers. Westerners struggled with the lack of specie and resented the East’s stranglehold on banking policy.”24 Western Virginians had neither the political control nor the capital to invest in their targeted improvements. These limitations on fiscal autonomy led western Virginians to commit to investments and acquire debt that enhanced connectivity to the rest of the Ohio River Valley region. Internal improvement projects improved these connections.

Easterners viewed western internal improvements as necessary for expanding the Commonwealth’s international presence and the respective debt should be shared throughout the state. Unlike the constitutional convention of 1829, the east now looked to incorporate the west's growing commercial capabilities into the east’s strategy to make Virginia into a global competitor. Railroads, canals, and turnpikes reflected important means toward becoming a central player in the growing Atlantic trade network. State leadership committed millions in public funds toward a statewide improvement plan. During the 1850 Constitutional Convention, political leaders focused on the shared burden of the investments. In the twenty years since Randolph accused westerners of buying their way into the political fold, easterners now focused on incorporating the west as a viable contributor to the Commonwealth’s future. Richmond’s R.C. Stanard challenged convention members to acknowledge the shared responsibility for the mounting debt: "The west is the growing portion of the state ... it already exercises a most potent influence over the subject of internal improvements ... and augment its population and wealth has the internal improvement debt of the

\footnotetext{
${ }^{24}$ Gruenwald, River of Enterprise, 111.
} 
State been swelled from one million dollars in 1829 to some eighteen or twenty million [dollars] in 1851." ${ }^{25}$ Eastern Virginians viewed the debt in terms of how the improvements influenced the west's access to the rest of the state. The promise and potential of the west changed how eastern leaders viewed the region and their spending. Since the convention in 1830 when Randolph raised concerns over a western willingness to use credit to "acquire" an elite status, the west now reflected a quasicolonial region that existed to provide resources for the east's benefit.

Western Virginians expressed the desire for autonomy by differentiating between debt that facilitated local commercial growth and debt created through state intervention. Internal improvement projects reflected a central area of political excitement and economic fantasy. However, in the Appalachian region, these improvements became essential investments in order for increased commercial growth and regional connectivity. In Kentucky, for example, the state understood the inherent rewards that could be realized by forming regional and communal connectivity. "Despite the issue of state debt, the completed regional turnpikes functioned as 'great baseline roads', effectively arterials to which local-scale neighborhood access roads could be connected." ${ }^{26}$ Internal improvements, despite the inherent debt associated with the project, reflected regional efforts to shape power and authority without the clear support of state leadership.

Prior to the development of their own projects, the National Road project placed Wheeling at the center of political discussions about economic development. When Ohio applied for statehood in 1802, Congress granted the request that a small portion of the state's land would be used for a road to traverse Ohio toward St. Louis. Subsequently, Congress authorized funds for a road to be built from Cumberland, Maryland to the banks of the Ohio River through Wheeling, which became a central

\footnotetext{
${ }^{25}$ Virginia Constitutional Convention, Robert H. Gallaher, and William G. Bishop, Register of the Debates and Proceedings of the Virginia Reform Convention, 1851, 24.

${ }^{26}$ Karl Raitz and Nancy O’Malley, “Local-scale turnpike roads in nineteenth-century Kentucky,” Journal of Historical Geography 33, no. 1 (2007): 9.
} 
intersection for western travelers. A traveling writer illustrated the Road's impact on Wheeling: "The transportation upon [the Road] of the eastern and western mail [carriers] made the Wheeling post office one of the largest distributing offices in the county. It had been an important auxiliary to the prosperity of the county and this portion of the country." Wheeling was on the national radar for its role in connecting the east and the west. The national investment was a significant $\$ 7.5$ million to construct and maintain the road from about 1818 to $1836 .{ }^{27}$ The National Road eventually became a costly and outdated means of transporting large supplies of people and material. While Virginia's political leadership focused on improving connectivity within their own state, western Virginians focused on internal improvements capable of linking the nation's east and west and re-positioning the region as a growing commercial and political power. The growing infrastructure provided western leaders with growing ambitions to compete in the growing national and international political economy.

Within Ohio County, two internal improvement projects reflect the region’s commitments: the Wheeling Suspension Bridge and the Hempfield Railroad. The bridge provided a clear example of Wheeling's interest in uniting the eastern and western portions of the United States. Crossing the Ohio River, the bridge transported large amounts of commodities carried by wagons and railcars. The bridge provided both Wheeling and the states around western Virginia with a point of geographic and political connectivity. Western Virginians also championed the Baltimore and Ohio’s Railroad (B\&O) Hempfield Railroad Extension. Linking Wheeling with Pennsylvania and Ohio, the Hempfield provided the region with a formal example of how the transportation innovations would enhance both western Virginia and the entire region. Both projects required public and private financial commitments. The debts to undertake these projects were investments

\footnotetext{
${ }^{27}$ J.H. Newton, G.G. Nichols, and A.G. Sprinkle, History of the Pan-handle: Being Historical Collections of the Counties of Ohio, Brooke, Marshall, and Hancock, West Virginia (Wheeling: J.A. Caldwell, 1879), $174,175$.
} 
western Virginians understood and supported within the confines of Virginia's broader internal improvement policies. Local interests conflicted with state interests. Historian John Majewski, in his comparison of Virginia and Pennsylvania antebellum internal improvements, argues that Virginia's intrastate urban rivalries, while not entirely unique to the Commonwealth, were a significant factor in how western Virginians understood internal improvements as being more local improvements versus statewide enhancements. ${ }^{28}$ Development costs were distributed across multiple parties and the benefits were recognized throughout the region. The Suspension Bridge and the Hempfield Railroad provided Wheeling and western Virginia with key political and commercial connections to Maryland, Pennsylvania, and Ohio. Understanding the development of both projects sheds light on how western Virginians shaped the meaning of debt to emphasize shared benefit and the national good.

The Wheeling Suspension Bridge provided a central point of passage for transporting people and materials along the National Road. More importantly, the bridge reflected western Virginians' willingness to assume public debt funded at the local level that led to greater regional solidarity and serve as an example of the west's ability to compete with the east with internal innovations. Civil Engineer Charles Ellet provided an annual report on the design and estimated resources required to construct the suspension bridge. Ellet praised the project for its design and influence on the region, "In the Wheeling Bridge, the entire cost of the cables for a single span ... has the advantage of leaving the navigation of the great river unimpeded [and] presenting an edifice, when finished, of far greater beauty and much more commanding effect.” The bridge’s costs were estimated at $\$ 210,000 .{ }^{29}$ The debt was a fair price for a project that would allow Wheeling to be a center piece in

\footnotetext{
${ }^{28}$ John Majewski, "The Political Impact of Great Commercial Cities: State Investment in Antebellum Pennsylvania and Virginia,” The Journal of Interdisciplinary History 28, no. 1 (July 1997): 17.

${ }^{29}$ Charles Ellet, Jr. Report on the Wheeling and Belmont Suspension Bridge to the City Council of Wheeling, (Philadelphia: J.C. Clark, 1847), 8.
} 
a great plan to link Ohio and eastern commercial centers. Ellet proclaimed that the costs were central to an improvement plan that was reliant upon Wheeling's central location: “I consider, therefore, that the Ohio Central rail-road must pass east and west through Ohio, touching at all the principal towns, and strike the river at Wheeling... and carry it on to the tide water." 30 Traffic on the National Road and several of the region's railroads would pass through Wheeling and toward the growing markets. The investment in the bridge served both the Ohio County community and the broader region. Western Pennsylvanians and Virginians reinforced their shared commercial and political interests through the extension of the Baltimore and Ohio $(\mathrm{B} \& \mathrm{O})$ railroad into the Ohio River Valley region. The collective interests of local investors and public administrators were bolstered through the adoption of the Hempfield Railroad. As an extension of the larger B\&O system, Hempfield linked western Virginians and Pennsylvanians. Both states shared in the joint financing through public bonds offered by Ohio County, Virginia and Washington County, Pennsylvania. Most importantly, the railroad reflected an important softening of the borders between Pennsylvania and Virginia. An 1852 Hempfield Railroad Company report proclaimed, “It is of great importance the geography of Virginia and Pennsylvania should be appreciated; for the charter granted to the Hempfield Rail Road Company is the only charter that has been conceded by the state of Virginia for any rail road passing ...from Pennsylvania into Ohio.” The total project was estimated to cost about \$2.7 million. Ohio and Washington Counties agreed to support the railroad’s development by backing the development costs with public investments. While Ohio County’s public debt in 1852 was $\$ 37,000$, the county agreed to acquire an additional $\$ 150,000$ in stock payments toward its fair share of the total costs required to develop the connection between Wheeling and Washington

\footnotetext{
${ }^{30}$ Ellet, Report on the Wheeling, 28.
} 
County. ${ }^{31}$ Agreeing to share the costs of the project was a key aspect to the Hempfield's successful completion. Similar to the suspension bridge, the bridge both defined and contributed to western Virginia’s interest in creating regional political stability in Ohio and Pennsylvania.

Although politically advantageous for westerners, the projects received less attention from eastern Virginians. Instead of public acclaim, the projects produced stories of salaciousness and audacity and served less as examples of regional glory. The internal improvements reconfirmed the western region’s untamed culture. Richmond’s Daily Dispatch reported how the bridge was conducive to suicide attempts and malfeasance. In detailing the multiple instances in which people were using the bridge to attempt suicide, the newspaper reported that “The suspension bridge at Wheeling is becoming decidedly famous as a crossing place for young women who wish to pass over the gulf which separates this world from the other." 32 Furthermore, the bridge served as a remote location for theft. After a series of failed attempts by local thieves, the newspaper reported, “... an attempt was made to file off the wire cables of the new suspension bridge over Wheeling ... but fortunately, the scoundrel was interrupted before he made progress." 33 These incidences reflected a notably different image of the bridge and its impact on Virginia’s political economy. Western Virginians understood this debt as a mechanism for attempting to maintain their own sense of authority and influence in the growing economy, while easterners viewed the improvements as immoral examples of impending dependency and failure. While western Virginians continued to acknowledge the need for legitimate indebtedness, they often struggled with state authorities that brought politically charged debt to the west through the county court system.

\footnotetext{
31 Hempfield Railroad Company, The Hempfield Rail Road, and the bonds of Ohio County, Virginia, and Washington County, Pennsylvania, (Philadelphia: John C. Clark, 1852) 19, 21.

32 “Another Heroine”, Daily Dispatch (Richmond, Virginia) March 8, 1855.

33 “Diabolical Attempt”, Daily Dispatch (Richmond, Virginia) December 4, 1856.
} 
Debt collection and lawsuits over indebtedness provided communities with central venues for bringing disparate sections together and disputing inherently political financial exchanges. Historian E. Lee Shepard signified the importance of the county courts in shaping the local community identity: "[County residents] much more readily thought of themselves as neighbors in a county setting. On court day, the gathering of fellow residents from across a county brought into sharp focus the shared needs, concerns, and interests of the local rural population.”34 Sheriffs and law enforcement officials maintained regional debt collection processes. Delinquent tax payers, insolvent debtors, or failed commercial investors interacted with county officials mediating debt issues. Residents from Ohio, Brooke, and Monongalia counties interacted with a cadre of creditors through the courts: railroad and canal developers, state-owned banks, and the federal government. Western Virginians developed conflicting insights into what debt meant in the current political economy. Commercial debt lawsuits reflected the price of autonomy and growth for the sovereign area. Government debt lawsuits, including those by state-owned banks, generated concerns that western Virginians were controlled and dependent upon the Commonwealth’s and national political leadership.

Debt collection was one of the most commonly occurring functions for local law enforcement and court systems. County courts provided an important setting in which multiple sections of society intersected. Sheriffs were responsible for collecting taxes required by federal, state, and county laws. Each year, the courts and the sheriffs worked in concert on tax collection efforts. Sheriffs and their constables would go throughout the county and collect taxes from the citizenry. After all collection attempts were exhausted, the sheriff constructed a list of all people who could not pay the levies. The copy of the list would be posted on the courthouse door and the

\footnotetext{
${ }^{34}$ E. Lee Shepard, “This Being Court Day,” The Virginia Magazine of History and Biography 103, no. 4 (October 1995): 460.
} 
delinquent tax payers would have a month to come forward to pay the debt. ${ }^{35}$ This process of publicly extracting debtors from the community emerges as a key political process in regions where opposition to taxes and financial burdens existed.

The county court system reflected a problem throughout the state because of the undue influence that justices could create through their punishments. Courts served as essential institutions for managing the affairs of local politics and financial issues. Debt-generated issues, which manifested from the lack of control over the capital and internal improvements, played out in the courts. While this matter did not reflect a form of eastern coercion or control, western politicians placed the court system as a key source in creating financial burdens. During an 1851 Constitutional Convention speech, Morgantown resident, Waitman Willey, addressed the "deficiencies of our present system of County Courts [and] the evils of the system as at present existing.” Willey argued that the approach for appointing justices was deeply flawed. Most of the judicial tribunals were "composed of men that have no knowledge of the laws they pretend to expound." The lack of justice tenures and the potential for fraud concerned Willey. These concerns, however, became most prevalent when the local community would be at risk by the court's role in managing tax debt and funding, "A justice who is interested in making the appropriation to be made will gather around him ... a sufficient number of other Justices to accomplish this objective, who direct the appropriation to be made." ${ }^{36}$ Willey’s argument, embedded within a broader concern over state taxation and political representation, linked western Virginian concerns between financial obligations and government interference. The County courts, prompted by state demands for tax revenues, influenced how

\footnotetext{
35 James M. Mathews, Digest of the Laws of Virginia of a Civil Nature and of A Permanent Character and General Operation: Illustrated by Judicial Decisions to Which are Prefixed the Constitution of the United States ; and the New Bill of Rights, and Constitution of Virginia (Richmond: J.W. Randolph, 1856), 469-470.

${ }^{36}$ Waitman Willey, Speeches of Waitman T. Willey of Monongalia County, Before the State Convention of Virginia on the Issue of Representation; on County Courts and County Organization and on the Election of Judges by the People (Richmond: William Culley, 1851), 29-30.
} 
western Virginians understood indebtedness. The perspectives were bolstered through the lawsuits that took place in western courthouses each year.

County debt lawsuits brought western Virginians directly in touch with a host of plaintiffs claiming reimbursement for failed public obligations to the federal, state, and local governments. Failed tax payments provided a contrasting form of debt payment from the traditional exchanges between a debtor and creditor. These debts were not produced from the exchange of promissory notes, currency, or materials. Instead, the debt was created by federal payments for national security and protection of American freedoms. Failed federal excise tax payments led to the 1817 case of The United States of America vs. Samuel Barr, Nicholas Moreland, and John Moreland. ${ }^{37}$ The case reflected the challenges presented by government intervention in the western Virginia region. A principal form of financial responsibility developed after America's wars was the collection of excise taxes on commodity production. One of the more politically controversial taxes was the excise taxes on whiskey. After the Revolutionary War, the national government assumed the states' war debts and the development of a national deficit. This decision increased the nation's access to greater levels of credit and finance. However, it also shaped the need to create excise tax programs to repay the significant public debt developed through the war efforts. One of the key measures the federal government deployed was a nationwide Spirits Excise Tax Act of 1792 that authorized states to have county-based inspection offices tasked with annually monitoring and tracking still production. ${ }^{38} \mathrm{~A}$ subsequent Excise Tax Act on distilled spirits was passed in 1813 and 1814 to cover the military debts incurred through the War of 1812. The case of the United States v. Samuel Barr was filed in 1817 for Barr’s failed tax payments of about $\$ 150$. The case reflected an important adjustment to

\footnotetext{
37 "The United States of America vs. Samuel Barr, Nicholas Moreland, and John Moreland” Envelope 58, County Court, Ohio County 1817, West Virginia and Regional History Center, West Virginia University.

${ }^{38}$ Thomas P. Slaughter, The Whiskey Rebellion: Frontier Epilogue to American Revolution (Oxford: Oxford University Press, 1986), 71, 73.
} 
how indebtedness was formed: the creditor was neither local nor a part of the regional community. Instead, the creditor was the United States soliciting payment for the exchange of national security and defense. ${ }^{39}$ As a political measure, the excise tax reflected a point of political debate and concern for the westerners. These types of pressures and concerns demonstrated by western Virginians reflected a broader issue that indebtedness was serving a larger role in influencing the nation's political economy.

The development of a global economy in which capital and credit flowed from anonymous financial institutions forced Americans to redefine how indebtedness supported the formation of political identities. For many nineteenth-century Americans, indebtedness ran contrary to the thriving spirit of economic independence and republicanism. To a degree, debt conveyed failure and immorality—characteristics that conflicted with the virtuous middle-class American citizen. ${ }^{40}$ These sentiments, however, ignored both the kinds of debt that developed and the political implications relating to the debt-related disputes. Western Virginians' perceptions of debt reflected important changes in the national economy. Debt could be acknowledged rather than disputed. Financial commitments became essential for adapting to the new market economy. A central factor in driving these changes was increased public sector involvement in sustaining and providing private sector offerings. Public officials intermingled concepts of public service (representation, taxation) with concerns of private offerings (corporate flexibility, revenue sharing). Americans began to understand debt in its bifurcated terms of

\footnotetext{
${ }^{39}$ Debt-related lawsuits between either the United States or Commonwealth of Virginia against a local debtor are relatively prevalent throughout the other western Virginia counties in the early nineteenth century. In 1816, for example, the United States served as a plaintiff in Monongalia County Court cases for resolution against a number of defendants for tax-related debts (see United States versus John Shively and Farguber Mona, Envelope 237; United States versus Enoch Jones and David Black, Envelope 237; and United States versus John Carrol, Envelope 237).

${ }^{40}$ Balleisen, Navigating Failure, 167.
} 
public commitment and commercial ambition. As western Virginians demonstrated throughout the antebellum period, Americans supported financial burdens for internal improvements, political solvency, and economic growth. However, taxation and public bonds thrust upon Americans, who were not clear as to either when or why they accepted the burden, remained a key source of political tension. Financial panics and crises were no longer defined in terms of failed exchanges between local, personal relationships. Instead, the financial disputes existed between regional financial and political institutions responsible to sustain the community's needs and requirements. The nation's political conflicts in the 1860s between secessionists and unionists changed the way in which political economy issues were resolved. Discussions over reputation and credit were now replaced with disputes over liberty and loyalty. The nation struggled to adapt to the rapidly changing market economy, which required Americans to accept responsibility for indebtedness incurred for public purposes, funded by private creditors, and shared by all.

Public responsibility for industrial development blurred the lines between commercial and public debt. State leadership used the interest of the people to drive publicly funded projects without concerns over rising public debt. The nation's need both to prepare for and exploit the growing international trade markets required community investments, interlinking commercial centers around internal improvement initiatives. Brian Murphy and John Larson highlight the manifestations of public-private investments and funding internal improvement projects with public funding produced the potential for risk. Murphy concludes his analysis of New York’s antebellum political economy by arguing that this type of environment blurred the roles of the public and private stakeholders. As long as state objectives were supported, "the corporations, monopolies, and other legal instrumentalities were hybrid mixed-economy creations that 
comingled capital and public authority, they were components of the state." ${ }^{41}$ These "instrumentalities" provided the funding mechanisms for internal improvement projects, as John Larson argued, that "drove lawmakers to plunge into debt on behalf of their constituents: in hopes of magnificent rewards ... but also in conscious self-defense against the demands of the people” who wanted to shape the nation's strongest political economies. ${ }^{42}$ Political representation and commercial success fed one another. In March 1859, North Carolina’s Moses Bledsoe articulated his defense of a program that minimized public debt incurred "on account of the various schemes of internal improvement." As was often stated in newspapers, "But this debt, for the payment of which the faith and honor of the State are pledged, was made for the benefits of all citizens and property in the State for promoting the general interest and prosperity of the state at large." ${ }^{43}$ Unfettered public spending on internal improvements underlined a rising dependency on financial investments to meet the public's growing transportation and commercial interest. The seeds of private dependency on public providers were sown in the decade before a civil war that dismantled public perceptions of the political economy.

The impact of credit and financial speculation, which drove panics, also served to change perceptions of risk for Americans. Banks unable or unwilling to provide customers with species payment for their local currency often led to banking crises or full-fledged panics. Transatlantic bank wars during the 1830s and 1840s provided Americans with an uncertainty in banks and their role in the economy. However, American commitments to more structured financing and access to credit served to acclimate Americans to financial turmoil and risk. Cultural historian Jessica Lepler focuses on the economic panic of 1837 as an important transformation in

\footnotetext{
${ }^{41}$ Murphy, Building the Empire State, 220-221.

42 John L. Larson, Internal Improvement (Chapel Hill: University of North Carolina Press, 2001), 224.

43 “Ad Valorem Taxation” Weekly Standard, (Raleigh, N.C.) March 16, 1859.
} 
American perceptions of financial risk. Lepler argues that "Individuals, communities, and even nations experienced different versions of the panic in 1837 colored by cultural, political and economic contexts ... [forcing each community] to reevaluate its local and national structures of political economy.” ${ }^{44}$ Ironically, increased interactions with panics and crises led to more adaptable understandings of how to manage them. The politics of banks and species exchanges remained a part of the American fabric throughout the nineteenth century.

The nation's formulas for establishing a coherent political economy, which included public investments in infrastructure designed to connect the nation's resources and services, was fractured by secessionist and unionist debates that led to a civil war. The competing political perspectives that created the split between eastern and western Virginians provided similar boundaries for a split between Virginia's Unionist and secessionist advocates. William Link simplified the distinction between western and eastern Virginians on the eve of the Civil War: "There was no true affinity between East and West, and the most distinguishing characteristic was slavery." ${ }^{45}$ Westerners had been deprived of control and influence. Most importantly, "Inequitable representation [and] a constitutional structure favoring slaveholders required them to pay an 'unequal share' of taxes.” As the state leadership converged in a final convention to vote on secession from the Union, Westerners began to focus on freeing themselves from a dependence on the east and becoming an independent state.

By April 1861, state leaders repeatedly converged to determine if the Commonwealth should remain in the Union or secede. Unionists articulated the need for commitment and loyalty to a federal government committed to investing in the protection of rights guaranteed by the Constitution.

\footnotetext{
${ }^{44}$ Jessica M. Lepler, The Many Panics of 1837: People, Politics, and the Creation of a Transatlantic Financial Crisis ( Cambridge: Cambridge University Press, 2013), 7.

${ }^{45}$ William A. Link, Roots of Secession: Slavery and Politics in Antebellum Virginia (Chapel Hill: University of North Carolina Press, 2003), 229-230.
} 
Eastern Virginian and secessionist Robert Montague argued that Virginia's role as a political leader of the minority perspective could be expressed through secession. Montague asserted, "Virginia was the first State on this Continent that ever exercised the great doctrine of secession [and] she did not go about to consult border States, to see what they would do. In the plentitude of her sovereignty, and in the depth of her patriotism, she severed her connection to the British government... ." ${ }^{\text {46 }}$ Eastern Virginians viewed secession as a means of exercising power as a member of a minority against a larger majority. Westerners responded by recognizing the value of revolution—when there was a collective benefit to be created. Unionist support, Chapman Stuart responded to eastern demands for secession by arguing westerners believed in the "right of revolution" if rights were being infringed upon and the Constitution legitimized perceived wrongs. However, this was not the case. Secession was the not "remedy of all evils [but] was the aggravation of these evils." ${ }^{47}$ Eastern Virginians, who placed their loyalties to a patriotic past and the roots of the nation, victoriously secured the vote for secession in April 1861. The Commonwealth of Virginia seceded from the Union. Within weeks of the decision, western Virginia focused on their own secession processes and gaining independence.

\footnotetext{
${ }^{46}$ William W. Freehling and Craig M. Simpson, Showdown in Virginia: The 1861 Convention and the Fate of the Union (Charlottesville: University of Virginia Press, 2010), 115.

${ }^{47}$ Freehling and Simpson, Showdown, 130-131.
} 


\section{Chapter 2: Who Is to Be Bound for This Debt? Resolving Issues of Debt during the Civil War and Reconstruction Era}

Western Virginians responded quickly. Eastern Virginians successfully secured the necessary votes to secede from the Union in the Commonwealth’s April 1861 convention. Virginia joined a southern confederacy focused on preserving a culture and economy built on states’ rights, slave labor, and an agricultural economy. Westerners rejected the convention's decision and mobilized to determine next steps. Morgantown residents created a series of resolutions reflecting their commitment to the Union: "Secession [from Virginia] is the only remedy for all real and supposed wrongs [and] the day is near when the West will ... dissolve all civil and political connections with the East and remain firmly under the Stars and Stripes." ${ }^{48}$ Western Virginia delegates, returning from the Commonwealth's convention, acted swiftly to capitalize on the regional cry for unity and Union. Within days of returning from Richmond, a meeting of 1,200 western Virginians converged in the town of Clarksburg-a commercial junction point on the Baltimore and Ohio Railroad that linked the state's eastern and western interests—and created a political plan of action focused on western Virginia’s independence.

Led by John Carlisle, western county leaders created a political manifesto, an address to the people of western Virginia declaring "that her people should be united in action and harmonious in purpose - there being perfect identity of interests in time of war as well as in peace.” Representatives from western Virginia agreed to meet in Wheeling to declare their "independence from the Commonwealth of Virginia and the reorganization of the commonwealth on a loyal basis.” 49 Carlisle's speech and the Wheeling Convention reflected a call to political action to expand the

\footnotetext{
48 Virgil Anson Lewis, History of West Virginia: In Two Parts (Philadelphia: Hubbard Brothers, 1889 ), $341-342$.

${ }^{49}$ Lewis, History of West Virginia, 342, 344.
} 
western Virginia political base and created a unified plan to secede from eastern Virginia. These events provided more western Virginians with broader opportunities to influence the course of the region. Of the delegates that converged in Wheeling, "only three had taken part in the Virginia Secession Convention earlier in the year." ${ }^{50}$ Regional leaders committed to political reforms that were democratic and proportionally representative to the interests of the entire region. After years of dependence on eastern Virginians, western Virginians rallied around regional solidarity and Union support that had been developing throughout the antebellum period. Regionally-dedicated internal improvement programs and a willingness to invest in the regional identity provided western Virginians with a stronger collective identity. Western Virginia’s roadmap included debt management processes that ironically did not produce the complete independence and financial autonomy that the political leaders sought. Instead, the political processes merely shifted the western Virginia dependency from eastern Virginia to the Union and actually increased the forms of debt that the new state would acknowledge.

West Virginia’s efforts to gain independence and achieve statehood were shaped by debt management processes that shifted political dependence from Virginia to Washington, D.C. during the Civil War and Reconstruction eras. The persistent need to resolve debt issues plagued the state's efforts during constitutional conventions and postbellum resolutions. The central processes of debt management—debt acknowledgement, debt accumulation, and debt resolution—accentuated regional and national political differences. Debt acknowledgement required West Virginia to contribute personnel and administrative resources to support the ongoing war effort. Through the constitutional conventions and drive for statehood, West Virginia’s political leaders acknowledged and accepted financial responsibility for the establishment of a new government and military. Debt

\footnotetext{
50 John E. Stealey III, West Virginia's Civil War-Era Constitution: Loyal Revolution, Confederate CounterRevolution, and the Convention of 1872 (Kent: Kent State University Press, 2013), 73.
} 
accumulation represented a political willingness to create financial obligations for long-term efforts and investment in regional and national identity. West Virginia’s commitments to regionally funded internal improvement projects were coupled with rising wartime obligations and political commitments to the Restored Government of Virginia and the Federal Government. The final element, debt resolution, complicated West Virginia’s new political position. Efforts to relieve debt responsibilities generated conflicting understandings of financial obligations and liabilities that left West Virginians unsure as to how to manage their debt issues. Debt management processes informed regional and national debates over constitutional amendments designed both to acknowledge and repudiate debt incurred for different reasons but in the same way. West Virginians' understandings of debt management — informed by national debates of honor and loyalty—led to a postbellum political standoff with the Commonwealth of Virginia about the long-standing public debt obligation.

Regional delegates used constitutional conventions to discuss credit, reputation, and honor to support their own claims to independence and condemn the actions of their opponents. During West Virginia’s constitutional debates, delegates attempted to fortify the region's commercial interests without following in the ill-fated footsteps of the eastern Virginians who joined the Confederacy. Preston County’s John Brown proclaimed, “It was said by John Randolph in the [Virginia] convention of 1829-1830 that no people who were desperately indebted could bear a regular and sober government. [Virginia] had run into debt and destroyed her reputation and credit in the world and went into secession... ."51 Ironically, western Virginians now agreed with eastern Virginian John Randolph that profligate spending was a source of state failure. However, it was not the prospective new state that would fail but Randolph’s Virginia. While Brown contended that the new state should

\footnotetext{
${ }^{51}$ West Virginia Constitutional Convention, William Burdette Mathews, Frances Haney Atwood, Charles Henry Ambler, West Virginia Constitution, and West Virginia. Debates And Proceedings of the First Constitutional Convention of West Virginia (1861-1863) (Huntington: Gentry Brothers, 1939), 166-167.
} 
learn from Virginia’s anticipated demise, the perspectives on fiscal conservatism were not universally shared. Wood County's William Stevenson encouraged public debt created through private investment as the most efficient and practical approach for planning the state’s finances: "[What] particular improvement [is] needed in this new state that private capital and private enterprise will not enter upon and accomplish ... more speedily than the State would do it?”52 The leaders of the presumed new state did not want to be overly cautious and waste the region's opportunity for glory. The commercial promises of political freedom required investment and advancement. While the Commonwealth had failed, western Virginians believed a balanced approach for investment and incurring debt could be struck. Harrison County's Thomas Harrison concluded, "It strikes me [that] the object of this section is not to prevent internal improvements by the State at all. But it is to provide that they shall be made on the most economical plan."53 Perspectives of debt, which drove efforts for independence during the antebellum period, now dictated West Virginia’s perspectives towards creating a new state that differed from the "mother country,” Virginia.

Debt management reflected an important national issue due to the changes in public spending that led to unprecedented spikes in public debt. While antebellum public debt grew due to regional investments in internal improvements, Civil War era public debt grew due to the national conflict over the preservation of the Union. In 1860, the federal government's public debt was $\$ 65$ million; by 1866 , the debt had grown to $\$ 3$ billion. Warring states amassed an estimated $\$ 468$ million in debt, respectively. ${ }^{54}$ These staggering increases in commitments and

\footnotetext{
${ }^{52}$ West Virginia Constitutional Convention, Debates And Proceedings, 165.

${ }^{53}$ Ibid., 170.

${ }^{54}$ United States Department of Treasury, Historical Debt Outstanding_Annual, (accessed March 1, 2016), https://www.treasurydirect.gov/govt/reports/pd/histdebt/histdebt.htm.
} 
obligations raised a key question: who was responsible for the debt? Anthropologist David Graeber asserts that all debt was "a perversion of a promise. [Debt] is a promise corrupted by math and violence.”55 The incurrence of debt during a time of conflict (Civil War) and reconciliation (Reconstruction) led to broken promises and debates over the promise itself. Addressing what the promise entailed dogged West Virginians' efforts for both statehood and autonomy throughout the remainder of the nineteenth century. Allegations of disloyalty and unfair political practices complicated promises of payment. Managing public debt as a public service to constituents became a political process that was debated, questioned, and adjusted to meet the needs of West Virginia.

Debt acknowledgement reflected the incurrence of financial commitments as a measure of loyalty and a willingness to share in the burden. Acknowledging debt during the Civil War reflected a political willingness to contribute to the ongoing military and administrative obligations deemed necessary to suppress the rebellion. In sum, this debt reflected unplanned and unclear investments that were made to support a shared outcome. During the eighteenth and nineteenth centuries, debt acknowledgement was used as a political tool for creating solidarity. Treasury Secretary Alexander Hamilton linked notions of debt and loyalty in the 1790s. Hamilton reformed the nation's political economy through a federal plan to assume state Revolutionary War debts as the basis for an excise tax that funded broad services, such as national security and infrastructure development. These actions created shared political interests financed by a shared common burden. Hamilton's plan created loyal allegiance by binding the public's financial interests to the government's interest. ${ }^{56}$

\footnotetext{
${ }^{55}$ David Graber, Debt: The First 5000 Year (Brooklyn: Melville House, 2011), 391.

${ }^{56}$ Thomas K. McCraw, The Founders and Finance: How Hamilton, Gallatin, and Other Immigrants Forged a New Economy ( Cambridge: Harvard University Press, 2012), 101-102.
} 
Western Virginia's attempts to achieve statehood required the acknowledgement of both new operating expenses and a long-term investment in Virginia’s public debt. A willingness to manage new financial obligations provided a first key step toward political unity and statehood. Regional delegates converged at the Wheeling Convention shortly after eastern Virginians decided to secede from the Union. Westerners established the political framework necessary to establish "a position of loyalty [and] a new and separate State in the glorious United States.”57 The Wheeling Convention promptly focused on establishing itself as the "Restored Government of Virginia" and creating the necessary infrastructure to operate a new government. As a precursor to statehood, western Virginians required the approval of its mother state (Virginia) to break away. Under the assumption that the Richmond government would never authorize such a secession, westerners promptly regrouped as the Restored Government. Western delegates, who now represented western Virginia and eastern Virginia interests, nominated Francis Pierpont as the new governor and Arthur Boreman as the president of the convention. In June 1861, the convention members passed several ordinances to reflect their control of the Commonwealth’s operations, including reorganizing the Virginia government, declaring the Richmond convention of 1861 null and void, calling up a militia, and appointing a state Treasurer and Auditor to manage finances. However, the most pertinent ordinance was passed on August 20, 1861: “An Ordinance to provide for the formation of a new state out of a portion of the territory of this state. ${ }^{58}$ While the original ordinance provided for a new state called Kanawha, the passing of this ordinance served as the basis for the state of West Virginia. The

\footnotetext{
${ }^{57}$ Virginia Convention Wheeling, Virginia, Journal of the Convention Assembled At Wheeling: On the 11th of June, 1861 (Wheeling, 1861), 19-20.

${ }^{58}$ West Virginia State Legislature, Ordinances and acts of the restored government of Virginia, prior to the formation of the state of West Virginia : with the constitution and laws of the state of West Virginia, to March 2d, 1866. (Wheeling: J. Frew, Public Printer, 1866) 6-16.
} 
Restored Government and the delegates of the proposed state now required federal support and authorization.

Federal acknowledgement of the Wheeling Convention and their proposed political changes reflected West Virginia’s inherent shift in dependence from Virginia to Washington, D. C. and acknowledgement of new debt. Pierpont promptly communicated to President Lincoln that the Restored Government stood ready to defend itself from the “evil-minded persons [who] had organized an insurrection and rebellion in the state to overthrow the government of the state.”59 Pierpont required federal approval and funding to create army regiments and offer commissions to officers to support the region's defenses against the Confederacy. President Lincoln authorized military support and provided funds for the military. This met the new government's defensive needs, but the state funded its own administrative and operational burdens. Western Virginians funded the Restored Government with nearly $\$ 90,000$ to establish public operations. Local banks provided a loan of $\$ 10,000$ for per diem expenses, $\$ 28,000$ in specie allocated for a public building, and \$50,000 from the federal government for financial support. These investments, while used to establish the Restored Government that relocated to Alexandria, Virginia, reflected western Virginia’s initial acknowledgement of the financial investments necessary for statehood. The dependence on the United States did not reduce West Virginia’s financial obligations; instead, the debt continued to increase as the nation's leaders debated West Virginia’s viability as a new state.

A willingness to share in the financial burdens emerged as an important aspect to the nation's adoption of West Virginia as a state. In December 1862, Kentucky’s John Crittenden debated on the House floor the legitimacy of western Virginia becoming a state if the debt issue was not reconciled.

\footnotetext{
${ }^{59}$ Francis H. Pierpont, 1861, Box 4; Folder 12; "Duplicate Fragments on the Organization of the Restored Government of Virginia,” West Virginia and Regional History Center, West Virginia University, Morgantown, West Virginia, 2-3.
} 
The public-private partnerships that led to Virginia's outstanding debt remained a concern for the Kentuckian who did not want to ignore the issues of broader fiscal responsibility and admit West Virginia into the Union. Virginia’s well-known public debt of nearly \$30 million dollars was an established fact and Crittenden needed assurances that if West Virginia was to be admitted, the debt would addressed. He implored the House leadership, “Mr. Speaker, there is another question to which I invite your attention. The old State of Virginia, when she embraced east and west, owed a large debt. She owes it today. Who is to be bound for this debt?” Waitman Willey assured Congress and Crittenden that the debt was being addressed through West Virginia's constitution. ${ }^{60}$ The West Virginia Constitutional Convention’s Finance Committee included a section in the proposed constitution that stipulated that West Virginia would assume responsibility for a share of the Virginia public debt and would pay for their share through a "sinking fund sufficient to pay the accruing interest and redeem the principal within thirty-four years.” ${ }^{61}$ Western Virginia’s debt acknowledgement demonstrated both a commitment to meet the public demands of the new state and the Union.

The price for statehood, however, included more than just the share of Virginia’s public debt. In 1863, Clarksburg's Thomas Harrison outlined the significant commitments that the state was signing up for: "The debt keeps accumulating upon us. We will have to shoulder our share of the Virginia debt, and it cannot be less than $\$ 6,000,000$, and at its lowest rate it will take at least $\$ 360,000$ [in annual payments]... . The United States is levying [a] direct tax on us of \$200,000 more.” In total, West Virginia’s annual debt was amounting to \$820,000. Congress saddled West

\footnotetext{
${ }^{60}$ United States Congress, The Congressional Globe: Containing the Debates and Proceedings of the Third Session of the Thirty-Seventh Congress. Washington D.C.. UNT Digital Library. (Accessed January 1, 2016) http://digital.library.unt.edu/ark:/67531/metadc30856/, 47.

${ }^{61}$ West Virginia, Ordinances and Acts of the Restored Government of Virginia, Prior to the Formation of the State of West Virginia : With the Constitution and Laws of the State of West Virginia, to March 2d, 1866. (Wheeling: J.

Frew, Public Printer, 1866), 16.
} 
Virginians with a significant tax debt and demanded that the new state address the Virginia public debt issue as a contingency of statehood. ${ }^{62}$ By 1863, Congress and the President recognized West Virginia as the nation's $35^{\text {th }}$ state. Through the process, however, West Virginia constitutionally and politically acknowledged significant liabilities that they would be accountable to repay. Resolution of the Virginia public debt remained a significant challenge throughout the remainder of the Civil War due to the bifurcation of eastern Virginia politics.

West Virginia’s political leadership believed that the region was on the cusp of both political and economic glory. With independence nearly in hand, antebellum goals of financing internal improvement projects that linked West Virginia with the broader Ohio River Valley remained intact. The political leadership confidently believed the state and its resources were positioned for future success and propped up their abilities to supersede the economic status of even the Virginia Commonwealth. Governor Arthur Boreman, in an 1863 message, acknowledged that prior to the war, the forty-eight West Virginia counties’ contributions exceeded the tax revenue contributions of the eastern portion that remained with the Commonwealth. The solid financial status combined with "the spirit of enlightened and patriotic statesmanship in the organization and administration of the government to establish the progress and prosperity of the new State” were the keys to West Virginia’s success. Permitting the accumulation of debt was necessary for economic development, but it also saddled the state with future payments. During the wartime constitutional conventions, West Virginia attempted to establish democratic processes for managing and administering state policies and lawmaking. Convention members debated allowing for constitutional amendments, effective taxation approaches, and internal improvement plans. Historian John Stealey argues that West Virginians rejected “[Eastern] Virginian tactics to thwart democratic reform by writing

62 West Virginia Constitutional Convention, Debates And Proceedings, 172. 
constitutions without a specific amendment process, by incorporating unenforceable possible remedies for reapportionment and leaving calls for future conventions in the hands of undemocratic legislatures ....”63 West Virginia’s government provided a superior example of an effective political economy that was democratically fair and fiscally responsible. Seemingly, West Virginia’s independence was legitimized by its citizens’ ability to self-govern more effectively. However, through each of its attempts to validate independence, West Virginians were actually shifting their dependence from eastern Virginia to Washington, D.C.

Debt accumulation processes adopted more rigid fiscal restraint in planning for future investments and obligations. State delegates argued for fixed caps on the amount of public debt that could be incurred. Unfettered spending on internal improvements required controlled planning. West Virginians fundamentally created a hard political line between their responsibilities as a member of the Commonwealth and their responsibilities as the stewards of their own resources. West Virginia, in optimistic hopes that the state would now be held responsible for only debts incurred by the new state, encouraged fiscal responsibility. Wood County’s Peter Van Winkle argued that accumulating debt without a clear plan to pay off the debt merely produced undue burdens for current and future generations of West Virginians. Van Winkle contended "contracting of another debt would damn the credit of the State in all the markets of the world.” 64 State leaders focused on proactively managing a potential public debt problem. J.W. Paxton, chairman of the Committee on Taxation and Finance, included several provisions in the new state’s constitution. Under Article 8, sections 5 and 6, the state would not contract debt or assume responsibility for county debt unless it was to pay for existing expenses, liabilities, or “defend the State in time of war.” Convention members, however, remained

\footnotetext{
63 John Edmund Stealey III, “West Virginia’s Constitutional Critique of Virginia: The Revolution of 1861-1863,” Civil War History 57, no. 1 (March 2011): 18.

${ }^{64}$ West Virginia Constitutional Convention, Debates And Proceedings, 132.
} 
unclear as to how the proportionality of the debt could be established if the public works were predominantly controlled by the seceded Virginians. Marion County’s Hiram Haymond argued, "It is considered by some that on a fair settlement with eastern Virginia we will not owe them one dollar. [Virginia's land] had been improved east of the mountains and they shall pay for the improvements.” ${ }^{65}$ Addressing Virginia’s public debt remained a challenge due to the unclear future of the Restored Government of Virginia and the state’s challenges in addressing their own debt issues.

Throughout much of the war, eastern Virginia interests were comingled between two state bodies: the original Commonwealth government in Richmond and the Restored Government of Virginia in Alexandria. Historian Sara Bearss detailed the state’s unique "two state system” that allowed eastern and western Virginian representatives to remain intact throughout the war. Specifically, the Richmond General Assembly admitted "representatives from the same northern Virginia and Eastern Shore counties that also sent representatives to the General Assembly in Wheeling [and] Alexandria ... . [Furthermore], Western Virginia counties continued to be represented in the General Assembly that met in Richmond during the war years even after referenda in those counties made them parts of the new state of West Virginia."66 This split form of political representation led to several unique challenges for both sets of leadership. It significantly influenced how Virginia managed and administered the political economy after the Civil War. Consequently, Virginian debt acknowledgement and accumulation—as a reflection of political support and commitment—-became largely dependent upon the outcome of the war itself and how debt would be administered during the post-war processes.

\footnotetext{
${ }^{65}$ West Virginia Constitutional Convention, Debates and Proceedings, 255.

${ }^{66}$ Sara B. Bearss, “Restored and Vindicated: The Virginia Constitutional Convention of 1864,” Virginia Magazine of History and Biography 12, no. 2 (March 2014). Academic Search Complete, EBSCOhost (accessed March 1, 2016).
} 
Virginia debt issues compounded during the 1860s largely due to the failed investment strategies and finances created by the war. The antebellum internal improvement projects were largely financed through joint public-private partnerships based on public bonds. Bondholders provided the necessary capital for state acquisition of stock for private development of railroads and roads. Theoretically, the state, as a shareholder, would utilize railroad profits to pay the interest owed to the bondholders. The destruction of Virginia's infrastructure during the Civil War compromised this approach and in the process, altered the state's ability to pay its debt. The revenue-generating railroads were destroyed during the war and Virginia’s ability to pay their debts ceased. Interest payments to bondholders were halted during the war and the debt grew to $\$ 41$ million by 1865 . Reconciling the debt became a key issue for Virginia's temporary leadership. In a private exchange between the governors in 1866, Pierpont extolled Boreman to "recommend and secure ... an act to raise a sinking fund looking to the payment of your Equitable share of the debt.” Pierpont minimized the debt's long-term risk to the new state: “[West Virginia] will have to pay for the amount of work done in W.Va on the Covington road perhaps [and] on the Winchester Road." ${ }^{\text {"7 }}$ After the war, West Virginia's postbellum political focus shifted toward expanding the state's influence and utilizing the state's resources to become a formidable member of the American political economy. Resolving the debt issue with Virginia continued to be a point of resistance for westerners against easterners.

During the Reconstruction era, perspectives over debt accumulation influenced Virginia's reentry into the Union. Virginia’s political debates no longer centered around internal improvements, representation rights, and the uses of credit and property as distinct forms of debt. Instead, managing debt emerged as a central issue for Virginians due to the very real concerns that the years of unpaid principal and interest payments would lead to both dishonor and insolvency. During Virginia's 1867

\footnotetext{
${ }^{67}$ Francis H. Pierpont to Arthur Boreman, December 19, 1866, West Virginia and Regional History Center, West Virginia University, Morgantown, West Virginia.
} 
Constitutional Convention, policy debates were anchored in concerns over debt. The Committee on Finance and Taxation provided a report of the State's financial strategy, which included 16 articles for the state's financial policy. Nearly all of these articles directly and indirectly addressed public debt. For example, Article 6 highlighted the state’s new commitment to minimize debt unless necessary for wartime protection, "No debt shall be contracted by the state except to meet casual deficits in the revenue to redeem a previous liability of the State, to suppress insurrection, repel invasion, or defend the State in time of War.” The state’s clear drive for transparency and accountability for the debt was captured by Article 16: “A full account of the State indebtedness an accurate statement of receipts and expenditures of the public money, shall be attached to and published with its laws ... .” Finally, Article 13 declared, "the State shall not be a party to, or become interested in the work of internal improvement, nor engage in carrying on any such work." ${ }^{68}$ Clearly, the Commonwealth switched priorities after the war. In order to progress, resolving the debt issue with West Virginia emerged as a major political reform issue.

Debt acknowledgement and accumulation provided the foundation for political debates over debt resolution and encompassed conflicting perceptions of political commitment and loyalty. Historically, the United States resolved public debt challenges through a two-part formula. The federal government assumed state debt and then issued taxes as a means of funding the debt. Federal assumption of state debt after the Revolutionary War and War of 1812 led to the use of an excise tax on whiskey. Southern rebellion costs complicated this formula. Competing public debts emerged in 1865: the federal government incurred debt to repel the rebel efforts and the Confederacy incurred

\footnotetext{
${ }^{68}$ Virginia, The Debates and proceedings of the Constitutional Convention of the State of Virginia, assembled at the city of Richmond, Tuesday, December 3, 1867: being a full and complete report of the debates and proceedings of the convention, together with the reconstruction acts of Congress and those supplementary thereto, the order of the commander of the First military district assembling the convention, and the new constitution (Richmond, Virginia Publishing, 1868) 400.
} 
public debt to stomp out an oppressive federal regime. Addressing these debts provided Union leadership with the means to mobilize southern support for federal obligations. States returning to the Union would be forced to acknowledge and contribute to paying the massive incurred federal debt. These principles shaped debt payment and repudiation in forcing southern commitment to the federal cause. In December 1865, Iowa’s congressman Hiram Price issued a resolution that stipulated “that no State recently in rebellion, ought to be entitled to representation, until such State shall ... adopt the [14 $\left.{ }^{\text {th }}\right]$ amendment to the Constitution, securing the payment of the national debt and repudiation of the rebel debt.”69 After the war, debt resolution merged the concept of political loyalty (paying national debt) with the concept of submission (repudiation of rebel debt).

West Virginia's leaders, who acknowledged the debt during the statehood debates, now balked at committing West Virginia's resources toward the efforts of a disloyal rebel state. After the war ended, state leaders engaged in a series of debates with Virginia's leadership either to resolve the debt issue or to rejoin the Commonwealth. Waitman Willey argued that a reunion would lead to significant setbacks that included, "the surrender of those fundamental reforms inaugurated under our new constitution, and the laws made by our legislature.” However, the key setback would be the impact of the enormous debt that grew during the war. Willey declared that rejoining Virginia would result in "enlarging our public debt for internal improvement, none of which would ever or could ever find their way into Western Virginia. In short, it would ruin us..70 Underscoring Willey’s concerns, however, was West Virginia’s loyalty to the Union cause: “we refused to follow Virginia into treason and rebellion. Virginia deserted us. She was the traitor." ${ }^{71}$ West Virginia’s secession from Virginia, once considered a temporary war measure, was now a reflection of its freedom from

\footnotetext{
69 “Congressional Proceedings”, The Daily Intelligencer, Wheeling, WV December 19, 1865.

${ }^{70}$ Waitman T. Willey, “A letter from Hon. W.T. Willey, on the Redintegration of Virginia” (Washington: 1866$) 6$.

${ }^{71}$ Willey, “A Letter”, 7.
} 
political and financial oppression. Loyalty to union was a reflection of West Virginia's dependence on the U.S. government and loyalty should have protected West Virginia from any additional responsibility to secessionist threats. West Virginia’s leadership could not resolve the public debt issue through reintegrating with Virginia or accepting responsibility for an estimated one-third of the \$40 million public debt. Acceptance reflected political regression. Instead, West Virginians would rely upon a stout commitment to the Union and a political settlement to resolve the debt crisis.

Virginia’s efforts to resolve its public debt controversy highlighted critical postbellum challenges of resolving debt incurred for the rebellion and for the sovereignty of the state. Political leadership understood that resolving the debt issue was critical for the state to transition from the failed war effort. Virginia's political leaders debated policies for "engrafting in the constitution being made an ordinance releasing the citizens of Virginia from said indebtedness ... and [determine] what portion of the present debt of this state was contracted for the purpose of aiding the late rebellion." ${ }^{\text {72 }}$ However, these efforts only led to the resolution of the debt covered by the $14^{\text {th }}$ amendment. Virginians' efforts to resolve the debt issue influenced state politics throughout the remainder of the nineteenth century. Incensed political reformers drove a readjustment movement in the late 1870s and 1880s. During the twenty post-war years, Virginia's politicians focused on restoring the Commonwealth's public and private credibility. Resolving the public debt was a central point of contention and focus. Virginia’s 1870 state legislature confronted a state debt of nearly \$45 million. "Readjusters" and "Debt Payers" emerged as significant political factions framing the divergent views about addressing the debt commitments.

Virginia’s state leadership created a plan that led to short-term debt relief and shifted political attention to West Virginia. Bondholders, who provided the initial funding for the internal

\footnotetext{
${ }^{72}$ Virginia, Debates and proceedings of the Constitutional convention of the state of Virginia, assembled at the city of Richmond, Tuesday, December 3, 1867, 441-442.
} 
improvement projects in the antebellum period, pressed Virginia’s government for payment of the principal and interest that accumulated since the 1850s. Through a political maneuver designed to pacify bondholders and pressure West Virginia into paying their portion of its state’s debt, Virginia's legislature passed the 1871 Funding Act that provided the funding for two-thirds of the outstanding debt. The remaining one-third was linked to bonded certificates that would be funded only when West Virginia paid Virginia for their portion of the debt. ${ }^{73}$ West Virginia continued to protest their overall obligations to Virginia. At the state’s 1885 Constitutional Convention, Virginia’s Democratic leadership declared, “The question of the State debt has ceased to be one [of] dollars and cents. It had become one of state sovereignty. We appeal ... to all men, irrespective of party, and invite them to unite with us in defending the imperiled rights of the Commonwealth.”74 Simply put, Virginia was now politically dependent on others to restore their autonomy and honor. Investors demand for payment and West Virginia's unwillingness to compromise forced Virginia to look outside their state to resolve the debt controversy.

Debt did not change during the Civil War and Reconstruction era; instead, the array of stakeholders and the amount of debt at stake shifted perceptions on political obligations and economic commitments. While Unionist and Secessionist debates precipitated the war, the United States focused on fostering nationalist sentiments throughout the country. As Drew Faust concludes in her assessment of the Civil War’s influence on the United States, “[The] United States’ new and elevated destiny became bound up with the nation itself: its growing power, its wealth, its extent, its

\footnotetext{
${ }^{73}$ Virginia Governor, Special Message of the Governor of Virginia Transmitting Report of the Commission Appointed on the Public Debt. (Richmond: James Goode 1892) 4-5. In addition to financing two-thirds of the existing debt, the 1871 Funding Act also acknowledged all of the unpaid interest that accumulated in the 1860s. As a result, Virginia actually paid about \$70 million in total debt payments during the Reconstruction era.

${ }_{74}$ "Repudiation and State Sovereignty." The Independent ...Devoted to the Consideration of Politics, Social and Economic Tendencies, History, Literature, and the Arts (1848-1921), Aug 13, 1885. (Accessed March 1, 2016) http://search.proquest.com/docview/90424307?accountid=2837.
} 
influence." ${ }^{\text {75 }}$ The Civil War era generated several reforms that produced changes in how debt was accumulated and how debt issues were resolved. Antebellum debates over the role of banks and currency were now mollified through concerns of national solidarity and fiscal conservatism. Throughout the nineteenth century, the failure of states to fund obligations led to public failures and defaults. More important, the inability to pay public debts spanned the entire century and was not limited to Civil War era defaults. In the early 1840s, nine states defaulted on the obligations and over 111 cities defaulted on public bond debt in the 1890s. This potential for public debt failure led many state governments to integrate effective financial management into their legal frameworks and processes. Unprecedented levels of state and federal debt spurred debates over how various debts were different and the political consequences of debt repudiation. Debt resolution emerged as either a formidable solution for absolving millions in unpayable debts or a shrewd mechanism for forcing southern rebels to acknowledge constitutional amendments and reforms. Richard Schragger argues that, "in an effort to rein in wayward legislatures and city councils, states embraced constitutional debt limitations, balanced budget mandates, public-purpose requirements, and other restrictions on debt and spending. The nineteenth century witnessed the rise of the 'fiscal constitution' in the states." ${ }^{76}$ West Virginia’s constitutional acknowledgement of incurring debt for operational purposes and placing ceilings on public investment represented the elements of a fiscal constitution. After the Civil War, West Virginia served as a model state for balancing and administrating effective financial stewardship and avoiding the pitfalls that prompted the debt controversy. The 1872 constitution reflected a progressive and financially sound framework that guided the new state through Reconstruction-era challenges.

\footnotetext{
${ }^{75}$ Drew Gilpin Faust, This Republic of Suffering: Death and the American Civil War (New York: Vintage Books, 2008), 268.

${ }^{76}$ Richard C. Schragger, “Democracy and Debt,” The Yale Law Journal, 121, no. 4 (January 2012): 863.
} 
The federal government's approach to managing the massive public debt transferred the inherent responsibility of economic solvency from the states to the federal government. The increased debt incurred through Civil War operations spurred the development of a financial system that mobilized large sums of capital and claimed control from the states over the distribution of currency and investment capabilities. ${ }^{77}$ The Civil War redefined the practical extent that the federal government could take to shape the American political economy. Nancy Cohen argues, "The Federal Government had exercised powers of revolutionary implications” such as emancipation of slaves and the Thirteenth Amendment that outlawed slavery in the United States. ${ }^{78}$ However, the federal government also utilized the unprecedented levels of public debt to urge reluctant southerners back into the Union and accept the abolition of slavery as a core element of a new political economy. Congressional leadership, through the Constitution's $14^{\text {th }}$ amendment, forgave rebel debt incurred during the Civil War. ${ }^{79}$ The national debt, from the Union's perspective, remained intact and would be paid through tax programs. This amendment reflected a continuation of the federal government's efforts to control the nation's financing activities.

This willingness to acknowledge rebel debt versus public debt came at a political price that was debated throughout the South. Debt repudiation provided a short-term benefit for a Virginia economy that was languishing. However, debt repudiation as a political maneuver was designed to justify a growing tax program and make debt resolution a national matter. Virginia’s Norfolk Post, in

\footnotetext{
${ }^{77}$ Nancy Cohen, Reconstruction of American Liberalism, 1865-1914 (Chapel Hill: University of North Carolina Press, 2002), 88.

${ }^{78}$ Cohen, American Liberalism, 27.

${ }^{79}$ Amongst the nation's constitutional changes ratified after the war ended, the Constitution's Fourteenth amendment directly addressed the debt incurred during the Civil War. The amendment's $4^{\text {th }}$ section stated, “ The Validity of the public debt of the United States, authorized by law, including debts incurred for payment of pensions and bounties for services in suppressing insurrection or rebellion, shall not be questioned. But neither the United States nor any State shall assume or pay any debt or obligation incurred in aid of insurrection or rebellion against the United States, or any claim for the loss or emancipation of any slave; but all such debts, obligations, and claims shall be held illegal and void."
} 
a November 1865 editorial, questioned the subversive nature of a national debt resolution policy designed to "compel the payment of the debt ... whether [the citizens] reside in Maine, California, or Texas would have to bear an equal proportion." ${ }^{80}$ Debt resolution provided federal leadership with a political tool to forge national solidarity. Virginians viewed debt repudiation as a means of diluting the state's authority and sharing responsibility for the payment throughout the nation. While Virginians viewed repudiation as an assault on their sense of honor and duty, the United States viewed the debt as being "against public policy, because [the debts] would be an encouragement to rebellion and thus a danger to the security and integrity” of the United States." ${ }^{81}$ Paying the public debt was both an investment and war measure necessary for restoring the political economy and security of the nation. While the $14^{\text {th }}$ amendment resolved the payment of public debt, West Virginia and Virginia remained unclear as to how their debt controversy would be resolved. This established the ironic dynamic that while debt repudiation created a clear avenue for Virginia to return to the Union, paying a fair a just proportion of the Virginia debt was the only avenue West Virginia could take to join the Union.

Paying equitable proportions of debt, however, had changed. West Virginia's inclusion of proportional measures in their 1861 constitutional debates was a reflection of regional and state solvency. The federal government now urged the shared responsibility required to pay down the debt and restore the Union. Debt resolution provided federal legislators with the means to fortify the nation. Loyalty would be measured through postbellum support for the federal government and the United States. This conflicted with West Virginia's rationale for agreeing to proportional payment of debt. West Virginia's diplomatic efforts to achieve statehood through recognizing a state debt failed.

\footnotetext{
80 “Southern War Debt”, The Norfolk Post (Norfolk, Virginia) November 1, 1865.

${ }^{81}$ James Barr Robertson, The Confederate Debt and Private Southern Payments (London: Waterlow and Sons, Limited, 1884), 16.
} 
The state included this language into their constitution at a point in time when the magnitude of the war and increase in public debt was unclear. Discussions between Pierpont and Boreman focused on West Virginia statehood and the triumph of the Alexandria government over the Richmond government when the war ended. Debt acknowledgement and resolution were tools—-not the end game — of the debates. The politicized debates over debt led to a showdown in the highest court in the land. 


\section{Chapter 3: Make No Deep Scrutiny Into Her Mutiny: The Supreme Court's Rulings in the Commonwealth of Virginia v. The State of West Virginia}

Virginia’s efforts to reconcile the public debt issue during the nineteenth century failed to create the compromises that the Old Dominion desperately needed. Interstate negotiations between Virginia and West Virginia bogged down after the war ended and devolved into a stalemate.

Virginia's statesmen grew concerned that the state's reputation and sovereignty eroded each day that resolution was not reached. The development of a Virginia Debt Commission in 1890 provided negotiators with the legal authority both to appease bondholders and use the power of the Attorney General's Office to settle with West Virginia. By contrast, West Virginia steadfastly maintained that legislative reforms, such as the Funding Act of 1871, absolved West Virginia of its responsibility for the antebellum debt. The two states exchanged criticisms leading up to Virginia's October 1906 filing of a judicial motion against West Virginia. Virginia argued that "Something had to be done in the way of adjusting the defaulted debt. All other efforts have failed to effect an adjustment; it was decided to appeal to the United States Supreme Court." ${ }^{82}$ Pressure from investors and other states placed Virginia directly in harm's way.

West Virginians, who disagreed with Virginia's sense of urgency, attempted to reposition the debate around accusations of dishonor and greed. In August 1906, West Virginia statesman James M. Mason, who would be elected chair of the West Virginia Debt Commission in 1913, proposed state congressional resolutions that suggested the Virginia debt commissioners "have brought suit against West Virginia for her share of the obligations, of graft.” Mr. Mason’s resolutions requested, "an interstate inquiry as to 'whether said Wall Street syndicates have agreed to pay the members of

82 “Old Dominion Now Wants Money Back”, The Washington Times (Washington, DC) March 08, $1906,9$. 
the [Virginia] commission large fees for their services in the matter.",83 Mason's accusations, while focused on graft and unethical behaviors, also reflected West Virginia's interest in keeping the matter out of the national spotlight. West Virginians, who depended upon federal support for statehood and the expansion of the state after the war, now were being called into the nation's highest federal court to resolve their debt disputes with citizens of another state.

West Virginia’s reluctance and Virginia’s subsequent Supreme Court filing reflected an increased dependence on the federal government for resolving political economy disputes. A series of Supreme Court filings between 1906 and 1918 framed the political debate between the Virginia and West Virginia. The debate focused on the Court's jurisdiction to resolve the debt controversy and the debt itself. The first issue centered around the use of the Supreme Court's original jurisdiction to resolve the dispute. ${ }^{84}$ The decision by Virginia to submit a complaint with the Supreme Court served as the Commonwealth's final option in resolving an interstate controversy as provided by the Constitution. In contrast, West Virginia rejected the Supreme Court’s involvement because the debt was a free market issue and not a constitutional matter. The second issue was the debate over the definition of fair and equitable proportionality. Simply put, while West Virginia constitutionally agreed to pay a proportion of the debt, the basis of this proportionality was never defined. Virginia unilaterally defined proportional allocation of the debt in terms of territory gained and lost by West Virginia’s secession from the Commonwealth. The final issue reflected Virginia’s and West

\footnotetext{
83 "Second District Democracy”, The Fairmont West Virginian (Fairmont, West Virginia) August 18, 1906, 3.

${ }^{84}$ Anne-Marie C. Carstens, "Lurking in the Shadows of Judicial Process: Special Masters in the Supreme Court's Original Jurisdictions Cases,” Minnesota Law Review 86, no. 3 (February 2002): 626. The majority of the Supreme Court's workload includes appellate cases in which the Supreme Court serves as the arbiter in cases that have passed through the local, state, and federal court systems. Supreme Court Justice William Rehnquist cogently defined the different jurisdictions as Original jurisdiction allows the Supreme Court to hear and decide a lawsuit in the first instance, while appellate jurisdiction means the authority to review the judgment of another court that has already heard the lawsuit in the first instance. Original jurisdiction cases reflected cases that superseded state courts and required federal involvement.
} 
Virginia’s dispute over the nature of the Supreme Court's decision making ability. Virginians viewed the Supreme Court's review as both a logical extension of their political processes and need for resolution. By contrast, West Virginians focused on the consequential monetary and taxation issues that inherently would be resolved by the case—which reflected issues of legislative rather than judicial authority. Understanding how both states and the Supreme Court addressed these issues reflected the strengthening of the national attitude toward debt resolution and federal intervention on state issues.

Virginia’s Supreme Court filing in 1906 was set in motion by the creation of the Virginia Debt Commission in 1890. The Commission consolidated the state's negotiation capability by forming a political body that created terms of repayment with a Bondholders' Committee-a body of investors and bondholders who demanded payment for the negotiated state bonds. The Commission and Bondholders' Committee reached an agreement in 1892 that provided the Committee members with “\$19,000 of new bonds for every $\$ 28,000$ of old bonds surrendered.” 85 This agreement, in theory, finalized Virginia's payments to the bondholders and shifted all outstanding payments to West Virginia. Of the approximate \$31 million in outstanding public bonds, this settlement claimed responsibility for over $\$ 23$ million and left the remaining \$8 million to be addressed through a compromise between the investors and West Virginia. In response, West Virginia protested the continued assertions of debt responsibility. West Virginia Governor MacCorkle, in an 1893 public letter, declared that West Virginia was a creditor and not a debtor to Virginia. The counties that created West Virginia “contributed \$4,000,000 and the expenditures within them by Virginia from 1822, the date of the first issue of Virginia bonds, was over a half million less, leaving ... Virginia in West Virginia's debt." ${ }^{86}$ MacCorkle’s comments reflected the sustained efforts to recast the public

\footnotetext{
${ }^{85}$ Virginia Governor, Special Message, 53.

86 “The Virginia Debt”, Spirit of Jefferson, (Charles Town, WV), December 12, 1893.
} 
debt as a byproduct of Virginia's control of the Commonwealth's political economy that predated both West Virginia’s rise and ability to influence state investments. MacCorkle’s facts obviously ignored the constitutional acknowledgement of debt incurred before January 1, 1861 and West Virginian’s prior debt acknowledgement.

The Virginia Debt Commission, after a decade of failed resolutions, obtained broader state executive support in 1900. The Commission received Attorney General support to create more pressure on West Virginia. In a 1900 legislative act, Virginia acknowledged that the "Commission shall be authorized and empowered by and with the advice and approval of the attorney general of Virginia to take such action and institute such proceedings on behalf of the State as may in the judgment of the commission and the attorney general ... to protect the interest of the state ... ."87 Virginia’s Randolph Harrison, through a declaration to the West Virginia legislature in 1901, implored the state's leaders to acknowledge the dire circumstances and settle the dispute. Harrison declared, “The contract under which the certificates are deposited ... will expire in September 1905 unless negotiations for a settlement, or some action looking to that end, have been undertaken.”88 Virginia's window for a settlement was closing and it needed West Virginia’s assistance to hold off the investors. The Bondholders Committee was principally managed by Brown Brothers and Company of New York. The Committee, which represented all investors and owned nearly 85 percent of the outstanding debt certificates, wanted to press their concern over the stalled negotiations.

\footnotetext{
${ }^{87}$ Virginia, Acts and Joint Resolutions Passed by the General Assembly of the Commonwealth of the State of Virginia During the Session of 1899-1900 (Richmond: J.H. O’Bannon, Superintendent of Public Printing, 1900), 903.

${ }^{88}$ Randolph Harrison, “West Virginia’s Contributive Share of the Debt of Virginia,” Virginia Law Register 10, no. 10, (April 1905): 1066.
} 
Harrison's plea fell on deaf ears. Virginia was entrenched in a political dispute between its investors and its former western counterparts. By 1905, the Debt Commission and Attorney General decided that the State’s options were exhausted. Brown Brothers and Company threatened to sue both Virginia and West Virginia for payment on the outstanding certificates. In his 1905 report to the Virginia Governor, Attorney General William Anderson provided, "We were also informed that holders of the large amounts of the Virginia deferred certificates proposed to donate a portion of their holdings to New York ... for the purpose of having an adjudication against Virginia and West Virginia for the liability of those States [and force payment of the bonds].” Brown Brothers and Company declared that it would lead a class action lawsuit against both Virginia and West Virginia to force a settlement. The banking firm maintained a reputation for being a thriving member of the New York City financial community that responded to threats with power. During the 1870 s, the Brown Brothers participated in the takeover of New York City's government from the corrupt Boss William Marcy Tweed. City officials gathered in the Brown Brothers' offices, and "the offices of the Brown Brothers became City Hall. For a few weeks, the committee ruled the city. It was a municipal coup d'état." ${ }^{89}$ The Brown Brothers reflected the rapid integration of private investors in the affairs of both contributing to and changing how government worked in the postbellum era. Virginians were succumbing to the economic power of New York's financial elite that represented an influential social actor who forged "their firms into the most powerful institutions of nineteenth century America." ${ }^{90}$ The investors represented a third party interest in settling the controversy but were also the most invested in a final outcome. Represented by Holmes Conrad, the investors ran out of patience with the states and signaled a readiness for legal action in 1905.

\footnotetext{
${ }^{89}$ Sven Beckert, The Monied Metropolis: New York City and the Consolidation of the American Bourgeoisie, 18501896 (Cambridge: Cambridge University Press, 2001), 182.

${ }^{90}$ Beckert, The Monied Metropolis, 3.
} 
The combination of investor pressure and recent Supreme Court decisions indicated that Virginia's best option for a final resolution with West Virginia was to ask the Court to resolve the interstate controversy. The growing bondholder unrest, when combined with the Commonwealth's nearly \$73 million in prior payments on the debts, prompted the Attorney General to recommend that the Governor file suit against West Virginia. Anderson concluded his report stating that while he was “exceedingly reluctant” to file a suit against West Virginia, the bondholders and creditors agreed that if Virginia "decree a suit against West Virginia for a settlement, they will release Virginia entirely from liability on account of the unfunded third of the antebellum debt."91 The politics of interstate disputes and finance would again be resolved in the Supreme Court.

Using the Supreme Court to resolve disputes over debt evolved throughout the eighteenth and nineteenth centuries through the Court's debates over who could sue for a debt payment and how debt payments could be enforced. As Laura Edwards argues, "Reconstruction-era policies [took] the national political rhetoric of the war years and [wrote] it into the legal order of the nation. The results ultimately extended the federal government's jurisdiction ... which came to be seen as the guarantor of liberty and equality." ${ }^{92}$ Interstate controversies continued emerging during the late-nineteenth century and the Supreme Court played a key role in maintaining civil conclusions over financial disputes. The Civil War changed the importance of the Court's involvement. Supreme Court Justice Henry Brown argued, "That a court having jurisdiction of controversies between States is an absolute necessity in a Confederation such as ours since war is practically the only alternative. It is true the Constitution ... provides that no State shall engage in war [with each other] but this is coupled with the provision that the Supreme Court should have the jurisdiction of controversies between the

\footnotetext{
${ }^{91}$ Office of Attorney General, Annual Report of the Attorney General to the Governor of Virginia for the year 1905 (Richmond: J.H. O’Bannon, Superintendent of Public Printing, 1905) 66-67.

${ }^{92}$ Laura F. Edwards, A Legal History of the Civil War and Reconstruction: A Nation of Rights (Cambridge: Cambridge University Press, 2015), 91.
} 
States... ."93 Two cases in particular, the 1883 cases of New Hampshire v. Louisiana and New York v. Louisiana, provided a judicial review of New York's and New Hampshire's ability to protect the economic interests of state residents with claims against other states. In the New Hampshire case, residents held Louisiana-issued bonds and wanted state support to receive payment for the bonds. Citing Eleventh Amendment prohibitions against private citizens suing states, the Supreme Court concluded that the real question was "whether a state can allow the use of its name in such a suit for the benefit of one of its citizens." ${ }^{94}$ Furthermore, the Court concluded "a state cannot create a controversy with another state ... by assuming the prosecution of debts owed to its citizens by a sister state.” 95 While the Court issued rulings in favor of Louisiana, the case raised a key point about a state's ability to file a bill of complaint to recover payment for debt owed by another state.

The Supreme Court's prolonged review of Virginia v. West Virginia traveled a circuitous route largely due to conflicting political perceptions over responsibility and proportionality of public obligations. The Supreme Court provided a venue for both states to engage in political disputes over resolving public debt. While each debate intersected with declarations of responsibility, loyalty, and political commitment, the dogged return of principal and interest payments required the parties to question how a debt should be paid. Virginia's initial position was shaped through the Bill of Complaint filed in the Supreme Court in February 1906. West Virginia’s positions were shaped through its demurrer, which rejected both Virginia's standing and the Supreme Court's jurisdiction in hearing the case. Finally, the Supreme Court's positions were shaped through their use of arbitrators (referred to as Special Masters) and their final decisions. Virginia's filing signaled significant changes in how each state should support fair and equitable responsibility for maintaining the

\footnotetext{
${ }^{93}$ Henry Billings Brown, "Interstate Controversies in the Supreme Court of the United States," The Advocate of Peace (1894-1920) 73, no. 1 (January 1911): 33.

94 Zimmerman, Interstate Disputes, Preface.

95 Ibid., 31.
} 
national economy. West Virginia's reluctance to agree to this responsibility led to the Supreme Court providing precedent-setting decisions and concluding the case.

Virginia’s position, established through the Bill of Complaint filed with the Supreme Court in October 1906, focused on the political agreements and constitutional adjustments that linked Congressional and Commonwealth statehood approval with West Virginia’s acknowledgement of paying a portion of Virginia’s public debt. Virginia's argument, grounded in nearly 40 years of legislative and diplomatic attempts to resolve the issue, linked West Virginia statehood to the payment of a debt. Virginians cited the acknowledgement of West Virginia’s constitutional framework, which included a willingness to pay a portion of Virginia’s debt, as the principle defense: “All three—Congress, Virginia and West Virginia—had to consent to conform to Art[icle] IV, [Section] 3 of the U. S. Constitution. Their three respective documents, together, constituted a contract between the old State and the new." ${ }^{96}$ Virginia now provided a multifaceted argument to the Supreme Court that linked West Virginia's willingness to pay a fair proportion of debt in return for statehood. Virginians claimed that West Virginia acquired about one-third of antebellum Virginia and in this process, West Virginia also assumed that fraction of the debt. This liability formed West Virginia’s political existence and was properly highlighted in West Virginia’s Constitution as a condition for statehood—-however, it did not bind the state to a measure of proportionality of predetermined sharing of the debt. West Virginia’s repeated legislative actions over the past forty years reflected an acknowledgement of the debt. In addition to linking the debt with territorial acquisition, Virginia also highlighted the Commonwealth’s transfer of real property to West Virginia to create a settlement. The final component of Virginia's bill was an acknowledgement of which people actually created West Virginia. Even though it was an action of the Restored Government of

96 "States: Adjustment of Public Debt between Virginia and West Virginia,” Michigan Law Review, 9, no.7 (May, 1911): 626. 
Virginia that led to the formation of West Virginia, the Restored Government was only made up of people interested in creating West Virginia. ${ }^{97}$ Virginia focused on forcing West Virginia and the Supreme Court to acknowledge that West Virginia independently created a contract with two possible outcomes: accept a portion of the debt as the price for independence or deny the debt and reject the contract that led to statehood.

Virginia argued that the Commonwealth’s citizenry endured their fair share of economic pain due to the questionable creation of West Virginia as a state. After the Civil War ended, Virginia made several attempts either to rejoin with West Virginia or reclaim portions of the new state. West Virginia rebuffed these efforts with claims that Virginia only delayed West Virginia in achieving its full promise as a state in the Union and the interest in rejoining were veiled attempts to replenish an exhausted treasury. Virginia responded to these rebuffs and focused on restoring the Commonwealth’s political economy and struggling through postbellum economic pain and suffering. Attorney General William Anderson focused the Court's attention on the timing of the Funding Act of 1871 and Virginia’s fragile state of affairs. Anderson argued, "Your honors will observe that by that statute the Commonwealth of Virginia, then just emerging from the war, with her fields devastated and many of her homes in ashes ... actually assumed not only two-thirds of the principal of the original debt, but assumed two-thirds of all the interest which had accrued upon it during the war interest ... .” This amount reflected a burden that far exceeded the public debt that existed prior to January $1,1861 .^{98}$ Virginia's Funding Act of 1871 was not merely completed to force West Virginia into paying a debt. The statute attempted to keep Virginia from defaulting on its obligations.

\footnotetext{
${ }^{97}$ Commonwealth of Virginia v State of West Virginia, Original, No. 7 (1906).

${ }^{98}$ Office of the Attorney General, Proceedings in the Equity Suit of the Commonwealth of Virginia vs. the State of West Virginia with an Appendix (Charleston: Tribune Printing, 1907), 328.
} 
Virginia’s counsel understood that if West Virginia wanted to explore matters of fairness and legitimacy, Virginia would raise issue with how West Virginia became a state in the first place. Counsel for the Bondholders, Holmes Conrad, poetically responded, “A child born through a Cesarean operation is as valid as one that comes into the world in the usual and ordinary way. As to West Virginia's genesis, and the legitimacy of her birth, you perhaps had better-'Make no deep scrutiny/Into her Mutiny/Rash and undutiful.." ${ }^{99}$ Virginia’s combined efforts—of resolving its own debt and tolerating the federal government's processes for accepting West Virginia into the Unionnow became the Commonwealth's strongest points for forcing West Virginia into a settlement for payment. By contrast, West disagreed with the entire case.

West Virginia responded to Virginia's Bill of Complaint with a demurrer rejecting both Virginia's legal standing in the case and the use of the Supreme Court's original jurisdiction to adjudicate the case. West Virginia asserted that there was no controversy between the states because the burden of payment now resided with the investors and certificate holders. This was a dispute that required free market intervention and commercial savviness and not a Constitutional dispute. The demurrer specified that there was no controversy between the states because "Virginia has been released from the payment of one-third of her debt contracted before the formation of West Virginia” and therefore, it is the certificate holders rather than Virginia that has an interest in resolving the debt issue. ${ }^{100}$ Through Virginia's multiple legislative reforms and the transfer of the certificates and bonds into the names of bondholders, did not give the Commonwealth "any right to maintain the suit in her name.”101 This was a dispute between a state (West Virginia) and a banking firm (Brown Brothers

\footnotetext{
99 Attorney General, Proceedings, 300-301.

${ }^{100}$ Ibid., 124,126.

${ }^{101}$ Ibid., 128
} 
and Company) over a matter of money. West Virginia was contending that since this was not an interstate controversy, the Supreme Court held no jurisdiction to resolve the case.

West Virginia, which depended upon federal intervention to achieve independence and statehood, now offered a demurrer against the federal government intervening on Virginia’s behalf. This was not a dismissal of the Court's original jurisdiction. Instead, West Virginia argued that the dispute was not a constitutionally defined controversy. The state’s argument was that Virginia's antebellum debt was resolved through its funding acts and the responsibility was transferred to the certificate holders. West Virginians declared that "The purpose of this suit is to settle the liability of West Virginia on these deferred certificates to the owners ... and any decree which is rendered in this case must relate solely to their rights. The court cannot enter any decree who are not before the Court either as plaintiffs or defendants.”102 The risk and the issue was a matter of cash payments demanded by private investors. West Virginia claimed that the Supreme Court's original jurisdiction could not be used because the dispute was reserved to States to resolve. West Virginia ignored its prior acknowledgement to pay a portion of Virginia’s debt as no longer relevant. The Commonwealth's funding acts erased the antebellum debt and any remaining debt was now owned by private investors. The demurrer asserted that "we perceive that as to this feature of the bill now under consideration, the court has no jurisdiction in any aspect of the case, nor can any amendment be made so as to give this court jurisdiction.” ${ }^{103}$ West Virginia could only resolve the issue with Virginia—not the creditors. The controversy between West Virginia and the bondholders did not constitutionally justify the Supreme Court's review because there was no interstate controversy. West Virginia also contended that the public debt issue was not the deciding factor for statehood; instead, it was West Virginia’s position on slavery and the investments West Virginia

\footnotetext{
102 Attorney General, Proceedings, 131.

103 Ibid., 133.
} 
made to establish a government. West Virginia’s Charles Hogg, a prominent statesman, agreed that constitutional agreements among West Virginia, Virginia, and the United States were key to West Virginia achieving statehood. However, the constitutional acknowledgement for paying a proportion of Virginia’s debt occurred prior to the final approval of statehood. Hogg insisted that West Virginia statehood was approved when the new state approved a proviso “That slavery shall be excluded from its boundaries. And when that was done, proclamation thereof should be made, and thereafter the proposed new state should be admitted into the Union." ${ }^{104}$ The constitutional acknowledgement for paying a proportion of Virginia's debt was less significant to the statehood vote than the amendment limiting slavery. Furthermore, West Virginia pointed to its investments and debts that made early statehood a fiscally challenging period for them as well. West Virginia argued that, while Virginia endured postbellum expenses and hardships, West Virginia experienced its own form of financial struggle prior to becoming a state. The demurrer stated that, “when [Virginia] parted ... the territory she parted with had to be erected into a state government, all the institutions necessary to its operation to be constructed, and great expense incurred [to achieve] the status of an independent state.” ${ }^{105}$ West Virginia and Virginia were not in a battle of equity that required the Supreme Court's attention. This was a matter of two states and investors debating a "simple money demand, because it was without power to make it effective.” ${ }^{106}$ West Virginia claimed only that the state legislature could settle the debt, as the only expected solution to this problem was either a state-funded taxation or public bond program to generate the necessary revenue to pay down any debt. ${ }^{107}$ Under the

\footnotetext{
104 Attorney General, Proceedings, 273-274.

105 Ibid., 140.

106 Ibid., 285.

107 James G. Randall, “The Virginia Debt Controversy,” Political Science Quarterly 30, no. 4 (December 1915): 571.
} 
current circumstances, West Virginians proposed ending the case and allowing the states to work toward a settlement through legislative means.

The Supreme Court disagreed in relatively short order with West Virginia’s demurrer and elected to proceed with the review of the case. Chief Justice Melville Fuller warned West Virginia not to question the enforcement capability of the Court. He provided a lengthy array of precedents that defined controversies and in the process, confirmed the existence of an interstate controversy between Virginia and West Virginia. The Court's response and dismissal of West Virginia’s demurrer foreshadowed West Virginia’s steadfast reluctance to engage fully in the judicial processes. Fuller reminded West Virginia’s counsel and representatives that, “'if the state should repudiate the decree or judgement, the Court would then consider means by which it might be enforced, that consent to be sued was given when West Virginia was admitted the Union’."108 The Court turned its attention toward the merits of Virginia's suit. The principal matter evolved into a question of fair and equitable allocation of the debt.

Virginia established its position on the matter of debt proportionality as early as 1871 and remained entrenched in the opinion that West Virginia owed one-third of the debt. Through Virginia's Funding Bill of 1871, the Commonwealth relied upon the size of the two partitioned states before the war to allocate one-third of the debt to West Virginia. Virginians believed that the debt should be reduced in proportion to the "impairment of the security on which [the debt] had been based — one third for the loss of West Virginia and one-third for the property destroyed by the war ...” served as a clear benchmark for determining responsibility. ${ }^{109}$ Virginia’s approach ignored the Commonwealth’s decisions to depart from the Union rather than force West Virginia to leave. Before

\footnotetext{
108 James Brown Scott, Judicial Settlement of Controversies between States of the American Union: An Analysis of Cases Decided in the Supreme Court (New Jersey: Lawbook Exchange, 1919), 457.

${ }^{109}$ Charles Chilton Pearson, The Readjuster Movement in Virginia (New Haven: Yale University Press, 1917$)$, 64.
} 
the war, eastern Virginians accepted responsibility for secession in order to maintain "her agricultural, her manufacturing, and her shipping interests." ${ }^{110}$ These efforts failed and now Virginians wanted to minimize the significant risks they had cultivated throughout the 1860s. The act authorized "interest-bearing coupons, instead of bonds, were to be issued for one-third of the debt, for which 'payment ... will be provided in accordance with such settlements between ... Virginia and West Virginia." ${ }^{111}$ Virginia repeated this similar course of legislative action throughout the remainder of the nineteenth century. The Virginia General Assembly enacted funding legislative relating to the debt in $1871,1879,1882$, and 1892 . Virginia's assembly encouraged bondholders to trade in existing bonds for certificates redeemable after a settlement between West Virginia and Virginia. The burden of payment to the bondholders remained the responsibility of Virginia from 1871 until 1892 — when the Virginia Debt Commission renegotiated terms of the bonds and unfunded certificates. Virginia could not afford to accept full responsibility for repayment and proposed a funding measure that intentionally fell short. The one-third measurement reflected a fair and equitable proportionality based on the distribution of territory. West Virginia disagreed.

The question of proportionality, although addressed by West Virginians in the initial Wheeling Convention ordinances, remained a central issue that required consensual agreement. West Virginian leaders rejected Virginia's postbellum legislative maneuvers that defined the level of West Virginia proportionality as one-third of the debt. The undefined term "proportion" provided West Virginia lawmakers with options. West Virginian representative J.M. Mason of Charleston distributed a pamphlet summarizing the debt controversy and provided options of how proportionality could be defined between the parties in 1884. Mason recommended: "Size of the two sections"-if so, West Virginia owed one-third of the debt; “relative populations"-if so, West

\footnotetext{
${ }^{110}$ Freehling and Simpson, Showdown, 10.

${ }^{111}$ Pearson, The Readjuster Movement,30.
} 
Virginia owed one-seventh; "relative amount of taxable property”-if so, West Virginia would be “light before 1830 and heavy after 1850”; “[total] expended on ... executive, legislative, judicial , fiscal, and police”- -if so, West Virginia would be heavy; "amount of revenue contributed” if so, the amount would be little before 1820 and a significant amount after $1850 .{ }^{112}$ Until the states could define proportionality, the debt issue would persist. However, another key aspect of Virginia’s assertion that bondholders would be paid after settlement between the two states was that West Virginia believed settlement should be between West Virginia and the bondholders and not with Virginia. The bondholders were subjected to loss and West Virginia, while unable to pay off 100 percent of the outstanding debt, could settle separately with the bondholders. The certificates only complicated the issue of repayment. West Virginians confidently believed that because Virginia did not have the authority to allocate debt responsibility unilaterally and that the debt certificates blurred the lines of who was still owed funds, the Supreme Court would support West Virginia’s claims.

While the Supreme Court evaluated the accounting treatment of the debt and asserted the Court's power to resolve the matter, the Justices largely spoke to the issue of proportionality in their decision. Justice Oliver Wendell Holmes issued the Court’s majority opinion in April 1911 and he spoke to West Virginia’s delays and requirements to be accountable. Holmes clarified that West Virginia's wartime constitutional acknowledgements of paying the debt remained intact even if there was a delay in creating an agreement with Virginia or West Virginia’s own Constitutional changes after the war ended. Holmes argued that the constitutional and legislative steps towards statehood were the basis for an agreement among the United States Congress, Virginia, and West Virginia. The Court would not refute the agreements that created West Virginia as a state. Instead, he asserted that the one issue that should be decided by the Court was the matter of proportionality. Holmes stated

\footnotetext{
112 James Murray Mason, The Facts about West Virginia's Equitable Proportion of the Debt Incurred by Virginia before She was Divided, West Virginia Regional History Collection, Pamphlet, P3773, 1881, 21-22.
} 
that the debt proportionality “is a judicial question" that the Court can decide. ${ }^{113}$ West Virginia benefitted from and contributed to the Commonwealth's decisions before the Civil War and the new state should be held accountable for a part of the outstanding debt. The Supreme Court determined a ratio based on "the estimated valuation of the real and personal property of the two states on the date of the separation. It seems plain that slaves as property should be excluded from this valuation.” Based on the amount of valued property that switched hands provided the most firm basis for determining West Virginia’s proportion. West Virginia’s fair proportion of the debt, which Virginia placed at 33 percent (one-third) of the antebellum debt, was now 23.5 percent of a total balance of $\$ 30,563,861$. West Virginia was responsible for $\$ 7,182,507 .^{114}$ The Supreme Court’s decision provided a resolution but not a conclusion to the dispute between Virginia and West Virginia.

The question of the debt's interest remained an outstanding question for both parties. Justice Holmes, in his closing remarks, attempted to encourage both parties to rise above their sectional interests through a commitment to the national good—which was a hallmark of Holmes’s postbellum reconciliation efforts throughout the late-nineteenth century. After the war, the former Union leader argued that the sense of devotion and commitment to a cause that led northerners and southerners to fight against one another should now be relied upon to support national glory. ${ }^{115}$ Holmes used similar sentiments in the Court's Opinion by declaring that "Great States have a temper superior to that of private litigants, and it is to be hoped that enough has been decided for patriotism, the fraternity of the Union, and mutual consideration to bring it to an end." ${ }^{116}$ Holmes’s optimism did not lead to a timely result. The court would continue to push both states towards a final resolution

\footnotetext{
${ }^{113}$ Commonwealth of Virginia v State of West Virginia, 220 U.S. 1 (1911) (Opinion of the Court)

${ }^{114}$ Commonwealth of Virginia v State of West Virginia, 220 U.S. 1 (1911) (Opinion of the Court)

115 David W. Blight, Race and Reunion: The Civil War in American Memory (Cambridge: Harvard University Press, 2001), 86.

${ }^{116}$ Commonwealth of Virginia v State of West Virginia, 220 U.S. 1 (1911) (Opinion of the Court)
} 
that would not be obtained until 1919. West Virginia remained reluctant to accept the federal government's intervention into their ability to resolve their own disputes.

The question of enforcement reflected the final issue for the Supreme Court to decide between Virginia and West Virginia. The Supreme Court’s decisions reflected opinions on judgement and application of the law. As the highest law in the land, the Court's decisions reflected the final position on a matter. However, in suits of equity between states, the Court traditionally stopped short of demanding that a state pay another state. In the 1904 case of South Dakota v. North Carolina, South Dakotan bondholders transferred bonds to the state to force North Carolina into paying a portion of the bonds. ${ }^{117}$ Similar to the Virginia vs. West Virginia suit, North Carolina argued that the Court did not have jurisdiction to settle the case and could not implement a decision to force North Carolina to pay. The Court debated if a decree could be issued that mandated the North Carolina legislature pass a tax program to satisfy the debts— - which they decided it could not; however, the Court did authorize "the marshal of the Court 'to sell at public auction all the interest of the public stock ... of the North Carolina Railroad Company.” This amounted to about \$27,400 in payment to South Dakota. ${ }^{118}$ West Virginia focused on the Court's precedent for advising against forcing a state pay another state. West Virginia’s unwillingness to work toward a joint resolution, as foreshadowed by Chief Justice Fuller, led the Supreme Court to mandate a resolution to be executed by both parties.

Following the Holmes decision, both parties followed a process that mirrored the previous ten years: Virginia doggedly attempted to resolve the debt dispute and West Virginia continued to protest the viability of the debt or the Court's ability to dictate the terms of any agreement. The

\footnotetext{
117 Office of the Attorney General, Annual Report of the Attorney General to the Governor of Virginia for the year 1905 (Richmond: J.H. O’Bannon, Superintendent of Public Printing, 1905), 66.

118 Joseph F. Zimmerman, Interstate Disputes: The Supreme Court's Original Jurisdiction (Ithaca: State University of New York Press, 2006), 145-146.
} 
Holmes decision determined the amount of debt principal that West Virginia owed to Virginia but the Court left the matter of the debt's interest to the states to decide. Virginia’s Debt Commission made several unsuccessful attempts with both the Supreme Court and West Virginia to expedite an agreement of a fair interest rate on the $\$ 7$ million that West Virginia was asked to pay by the Court. Virginia Attorney General, Samuel Williams, reported to the Virginia governor in 1912 that "The United States Supreme Court having refused to speed the cause until the meeting of the West Virginia legislature ... nothing has been done in the case since [the Court's final decision].”119 Virginia and West Virginia representatives met in 1913 to debate the issue of interest. West Virginia's interpretations of the Court's decision as a suggestion of debt resolution rather than a decree of execution continued to draw out the debt controversy.

West Virginia finally created its own debt commission to confer with the Virginia Debt Commission in Washington, D.C. to resolve the debt issue in 1913. While Virginians entered the discussion presuming that the central topic would be the development and agreement on an interest rate, West Virginians wanted to review the entire case. ${ }^{120}$ West Virginia's Debt Commission chairman, John Mason, contended that West Virginia did not see the Supreme Court's decision as a decree but rather as a suggestion: "We do not consider at all that the Supreme Court has settled the amount. It has indicated a basis. It took a different one from yours or ours, either one. You suggested [proportional distribution based] upon the basis of population, and ours was upon taking the Wheeling ordinance. They said both [rationales] were wrong, and in their report took the taxable values.”121 Furthermore, West Virginia viewed the conference as "a matter of compromise between

\footnotetext{
${ }^{119}$ Office of the Attorney General, Annual Report of the Attorney General to the Governor of Virginia for the year 1912 (Richmond: Davis Bottom, Superintendent of Public Printing, 1913) 5.

${ }^{120}$ Commonwealth of Virginia v. State of West Virginia, 234 U.S. 117 (1914).

${ }^{121}$ Office of the Attorney General, Annual Report of the Attorney General to the Governor of Virginia for the year 1913 (Richmond: Davis Bottom, Superintendent of Public Printing, 1914) 15.
} 
the two commissions. We do not want to meet as if still carrying on a lawsuit.” ${ }^{122}$ West Virginia attempted to reestablish the dispute as a regional conflict that did not require federal intervention and the national courts to drive toward resolution. West Virginia's efforts reflected the state's persistent perspective that the only acceptable solution was one that was created by and enforced through the state’s legislative processes. Virginia disagreed and once again, returned to the Supreme Court for support.

The Supreme Court provided West Virginia with additional time to craft a settlement and again, West Virginia delayed in resolving the case. In the October 1913 term, the Supreme Court decided that, "Having regard to these representations, we think we ought not to grant [Virginia’s] motion to proceed at once to consider and determine the cause, but should ... comply with the request made for further time to enable the Commissioners of West Virginia to complete the work for the purpose of effecting a settlement of the controversy."123 With the additional time, West Virginia constructed a new settlement offer for Virginia’s consideration. Based on West Virginia’s arguments that the state was not compensated for a share of Virginia's profits of certain stocks, bonds and property, the actual debt should be $\$ 2.3$ million. ${ }^{124}$ Virginia objected to the proposal. The Supreme Court's 1911 decision defined the debt principal and the only remaining matter was the interest. The Commonwealth's legal team motioned the Court to enforce its decree and demand that West Virginia resolve the issue of interest rates. The Supreme Court, once again, brought in an independent arbiter who assessed 60 years of financial transactions and recommended terms of principal and interest payment that would resolve the debt controversy.

\footnotetext{
122 Attorney General, Annual Report of the Attorney General to the Governor of Virginia for the year $1913,14$.

123 Ibid., 34.

${ }^{124}$ Ibid., 141.
} 
The Supreme Court made its final decision in 1915 and this time, West Virginia was provided with no additional latitude to refute the decisions. The court decreed that West Virginia's total obligation, with principal and interest combined, was $\$ 12,393,929.50$. West Virginia continued to delay acceptance of this decision and insisted the state legislature was the only body that could create and execute a decree to fund the debt. The Supreme Court's decisions were mere suggestions. After several more years of West Virginia declaring that the Supreme Court could not enforce its decision, the Supreme Court finally directed West Virginia to accept the final decree and pay Virginia. In 1918, the Supreme Court explained to West Virginia’s representatives that “The court held it possessed the authority to enforce a decree by appropriate proceedings against a state [and] Congress possesses [the authority] to control agreements between states.” Furthermore, the Court acknowledged that they were not going to close the case and "reserved the right, if necessary, to appoint a special master to examine and prepare" the methods for taxation and enforcing the judgment. West Virginia’s legislature increased taxes and created a public bond program to pay back the debt. Chief Justice Edward White, attempting to avoid any additional obstacles, deemed that the Court reserved the right to "appoint a master for the purpose of examining and reporting concerning the amount and method of taxation to be put into effect... ." ${ }^{125}$ Simply put, the Supreme Court asserted federal authority over West Virginia and mandated compliance. ${ }^{126}$ West Virginia’s acquiescence was created through legislative reform and the Virginia Debt Controversy was resolved.

The Supreme Court's decision restored Virginia's reputation and was hailed as a victory for the banking industry and private investors who waited decades to reap the gains of their investments. Philadelphia’s Evening Public Ledger declared, “After a long series of years, during which [the case]

${ }^{125}$ Commonwealth of Virginia v. State of West Virginia, 246 U. S. 565 (1918).

${ }^{126}$ Zimmerman, Interstate Disputes, 147. 
dragged through the courts, the famous West Virginia debt case has at last been settled, thanks to the persistence of Brown Brothers \& Co.” West Virginia’s state legislature, on April 1, 1919, enacted legislation that provided the final solution to the debt controversy. The West Virginia Treasurer drew a check "out of any funds available ... and deliver [a] check to the Commonwealth of Virginia” that reflected a credit to Virginia for the outstanding interest that had accrued since the Supreme Court's 1915 decision. ${ }^{127}$ West Virginia’s Treasurer issued a cash payment of \$1,078,662 — the single largest interstate cash payment. Furthermore, West Virginia would issue \$12,366,500 in coupon bonds. The coupon bonds were twenty year gold bonds that $3 \frac{1}{2} 2$ percent interest that would be distributed "over a period of 20 years, beginning with the date of the bond and ending with maturity.” Finally, West Virginia created \$1,133,500 in reserve bonds. The reserve bonds would be issued in payment for any outstanding Virginia Deferred Certificates which "may have been lost or destroyed [and] not certified as deposited with the Commonwealth of Virginia ... ."128 This financial resolution provided Virginia with a comprehensive resolution to the long standing challenge. In 1919, Virginia Auditor Rosewell Page argued concluded the analysis of the controversy by contending Virginia "removed from her good name the imputation of being a repudiator." 129

The Supreme Court's acknowledgement of Virginia's position—-that West Virginia did owe a portion of the debt—reflected an important change to the political memory of West Virginia's addition to the Union. When West Virginia joined the Union in 1863, President Lincoln "attached greater importance to recognizing the claims of loyal people of West Virginia than concerns about future difficulties in restoring secessionist Virginia to the Union. Moreover, [admitting West Virginia helped in] reconciling many western leaders to the Emancipation Proclamation.”130 West Virginia no

\footnotetext{
${ }^{127}$ Rosewell Page, “The West Virginia Debt Settlement,” The Virginia Law Register 5, no. 4 (August 1919), 279.

128 Page, “West Virginia Debt”, 279-280.

${ }^{129}$ Ibid., 283.

${ }^{130}$ Otis K. Rice, West Virginia: A History (Lexington: University Press of Kentucky, 1985), 150.
} 
longer carried the same political weight that it did during the war. The Court's acceptance of Virginia's arguments reflected a continuation of cases adjudicated in the 1870s and 1880s that severely circumscribed the Fourteenth and Fifteenth amendments and returned power to the states at the expense of the federal government. Furthermore, this case reflected a continued amelioration of relations with southern states at the expense of West Virginians who had used territorial acquisition and the transfer of real property as a means of supporting the Union; the Supreme Court now viewed the same factors as the basis for Virginia to be repaid. The public debt settlement highlighted Virginia's continued emergence as a center of political and economic reform and West Virginia's continued battle to meet wartime expectations and overcome their colonial dependence.

West Virginia's final acknowledgement reflected the opportunity cost for its prior dependent relationships on Virginia and the Federal government. After the Civil War, West Virginia's economy did not produce the financial gains that either Virginia or the federal government envisioned in the nineteenth century. West Virginia's shift from relying upon the federal government to asserting its own sovereign control to reconcile the debt reflected a regression in the state's political processes. Changes created through the Civil War and Reconstruction era shifted political dependence from the regional level to the national level. However, West Virginia’s political reforms of the late-nineteenth century underscored West Virginia's continued subordinate status. The Supreme Court's decision comprised West Virginia's efforts to both declare and maintain independence. Interstate commerce complicated financial exchanges and state governments could no longer be the sole mediator in resolving financial disputes. The administration of financial failure and fiscal obligations evolved into a nationalized political issue by the early twentieth century. West Virginia's judicial arguments for states' rights conflicted with the nation's trend for developing uniform treatment of the debtor and creditor relationships that now served as the basis for the political economy. 


\section{Conclusion: A Fair and Equitable Proportion}

West Virginia settled its debt, and the negative impacts of that settlement became apparent. Throughout the 1920s, reminders of the defeat and examples of Virginia's return to power provided West Virginia with ample frustration. With West Virginia’s tax rates increasing in order to sustain the terms of the debt settlement, Virginia continued to benefit from a warm relationship with the Federal Government. The New York Herald, in April 1921, headlined, “Amiable Debt Settlements: Virginia and the Federal Government Friendly Over Century Old Claims.” Virginia identified unfunded claims, such as Virginia’s contribution to federal spending during the Mexican War, that were peacefully resolved between the federal and state authorities. ${ }^{131}$ By contrast, West Virginia continued subsidizing Virginia’s projects and growth. The Richmond Times-Dispatch reported in April 1922 that a Virginia building "cannot cost more than $\$ 750,000$. In order to obtain the necessary money, [the Brewer Bill] authorizes the Governor to dispose of the bonds of the State of West Virginia received by the State as part of its shares of the proceeds of the Virginia-West Virginia debt settlement." ${ }^{132}$ West Virginia’s political philosophy of creating a new state grounded in fairness and equality was not realized in the manner that Carlisle and Willey planned.

West Virginia’s involvement in the Supreme Court case highlighted a shift in the state's political economy, which occurred throughout the nineteenth century. The term "equitable proportion” of the public debt became a matter of legend for West Virginia. Each political generation attempted to reconcile why the public debt was acknowledged and what the debt represented. During the nineteenth century, states controlled their political economies and

\footnotetext{
131 “Amiable Debt Settlements”, The New York Herald (New York City, NY) April 12, 1921.

132 “ Proceeds from Sale of West Virginia Bonds to be Used in Paying Bill,” Richmond Times-Dispatch (Richmond, Virginia) April 6, 1922.
} 
administered their interactions with "political outsiders.” West Virginia’s settlement with the Supreme Court reflected an important transition in public debt resolution processes. While debt provided opportunities for independence from Virginia, it also led to dependency on the federal government. During West Virginia's constitutional convention of 1862, Waitman Willey recognized the political value of claiming a portion of a debt rather than waiting for a superior authority (Virginia or the federal government) to impose a debt. Willey counseled his fellow West Virginians that assuming a just and equitable proportion of the Virginia debt "is eminently right and proper. What will [the debt] be when the war is terminated? Give us a new state [of West Virginia], and our existing rates of taxes will be lessened. Remain as we are, and they must necessarily be increased more than tenfold." ${ }^{\text {33 }}$ Constitutionally acknowledging a portion of the debt reflected confidence in West Virginia’s actions and ability to navigate the politically tumultuous waters of the 1860s. By contrast, West Virginia's inability to settle the debt issue in the twentieth century reflected West Virginia's protracted sense of political inferiority that was at the core of the state's economy.

Despite 40 years of “independence” from 1860 to 1900, West Virginia’s political economy was postcolonial in nature. Inferior and dependent, West Virginia's failed reconciliation over the public debt issue framed the century-long transition of the state's political economy. State leaders sought a political economy in which taxes and political representation— and the public debt—would be based on a fair and proportional basis. Antebellum West Virginians tried to create and manage their own debt as a means of liberating themselves from Virginia’s eastern powers. State delegates agreed to fund a fair and equitable proportion of Virginia’s debt as an expression of West Virginia's control and power to set the terms of

${ }^{133}$ West Virginia Constitutional Convention, Debates And Proceedings, 489-490. 
negotiation with eastern Virginians. However, these political concessions merely transferred their dependence to the Union government and the northern investors who continued to control West Virginia interests from a distance. This process reinforced the establishment of a postcolonial political economy that remained both inferior and dependent on outside entities for political power.

The prevalence of outsiders both to create and extract value from West Virginia occurred throughout the nineteenth century and typified the state's political economy. Historian John Williams summarized West Virginia’s shortcomings of the early twentieth century: “The creation of a new and unformed polity in a territory almost wholly subject to the social impact of extractive industry resulted in a phenomenon described as a colonial political economy.”134 West Virginia's extended history of dependence did not end in the 1860s and more importantly, the Supreme Court's decision indicated that the political economy was firmly in a state of postcolonial dependence. Revolutionary Era historian Kariann Yokota argued that "The experience of being judged by the standards of a distant metropole as inferior and uncivilized informed a wide variety of social practices.” ${ }^{135}$ Nineteenth-century West Virginia struggled to become an independent political entity. Yokota’s illustration of the British “refusal to recognize the right of the U.S. government to define the terms with which they conferred citizenship” served as a parallel example to the Supreme Court's later refusal to allow West Virginia to define the terms of interstate negotiations. ${ }^{136}$ Fundamentally, West Virginia's inability to resolve the

\footnotetext{
134 John Alexander Williams, West Virginia and the Captains of Industry (Morgantown: West Virginia University Press, 2003), 1.

${ }^{135}$ Yokota, Unbecoming British, 239.

${ }^{136}$ Ibid., 231.
} 
public debt issues contributed to the development of a postcolonial political economy throughout the nineteenth century and early twentieth century.

West Virginians fundamentally maintained a political economy that traded in one overlord (eastern Virginians) for another (Northerners) who wanted West Virginia to become a proxy for their interests. Anthropologist David Graeber argued that debts were created through exchanges fluctuating between equality and separation: "Debt is what happens in between [the exchange and the repayment]: when the two parties cannot yet walk away from each other, because they are not equal.”137 Simply put, debt placed West Virginia in a dependent condition to other political authorities that limited its political authority and solvency. A struggle for equality and the ability to influence the Commonwealth's political direction and the Supreme Court's decision was stymied by unaddressed public debts throughout the nineteenth century.

${ }^{137}$ Graber, Debt, 122. 


\section{Bibliography}

\section{Primary Sources}

Archival Materials

Pierpont, Francis H. 1861. Box 4; Folder 12. "Duplicate Fragments on the Organization of the Restored Government of Virginia". West Virginia and Regional History Center. West Virginia University. Morgantown, West Virginia.

Pierpont, Francis H. to Arthur Boreman, West Virginia and Regional History Center. West Virginia University. Morgantown, West Virginia.

Willey, Waitman Thomas. A letter from Hon. W.T. Willey, on the Redintegration of Virginia. 18111900.

Mason, James Murray. The Facts about West Virginia's Equitable Proportion of the Debt Incurred by Virginia before She was Divided. West Virginia Regional History Collection, Pamphlet, P3773, 1881, 21-22.

Newspapers

Spirit of Jefferson (Jefferson County, WV)

Cooper's Clarksburg Register (Harrison County, WV)

The Intelligencer/ Wheeling Intelligencer (Ohio County, WV)

Daily Dispatch (Richmond, VA)

Staunton Spectator (Staunton, VA)

Weekly Standard (Raleigh, NC)

The Norfolk Post (Norfolk, Virginia)

The Washington Times (Washington, DC)

The Fairmont West Virginian (Fairmont, WV)

Spirit of Jefferson (Charles Town, WV)

The New York Herald (New York City, NY)

Richmond Times-Dispatch (Richmond, Virginia)

\section{Government Documents}

West Virginia. Ordinances and acts of the restored government of Virginia, prior to the formation of the state of West Virginia : with the constitution and laws of the state of West Virginia, to March 2d, 1866. (Wheeling: J. Frew, Public Printer, 1866).

Virginia Constitutional Convention. Robert H. Gallaher and William G. Bishop. Register of the Debates and Proceedings of the Virginia Reform Convention. 1851. 
Virginia Constitutional Convention. Proceedings and Debates of the Virginia State Convention of 1829-1830: To Which Are Subjoined the New Constitution of Virginia, and the Votes of the People. Richmond: Samuel Shepard and Company, 1830.

Virginia Constitutional Convention. Proceedings and Debates of the Virginia State Convention of 1829-1830. New York: De Capo Press, 1971.

Willey, Waitman Thomas. Speeches of Waitman T. Willey of Monongalia County, Before the State Convention of Virginia on the Issue of Representation; on County Courts \& County Organization and on the Election of Judges by the People. Richmond: William Culley, 1851.

Hempfield Railroad Company. The Hempfield Rail Road, and the Bonds of Ohio County, Virginia, and Washington County, Pennsylvania. Philadelphia: John C. Clark, 1852.

Ellet Jr., Charles. Report on the Wheeling and Belmont Suspension Bridge to the City Council of Wheeling. Philadelphia: J.C. Clark, 1847)

University of Virginia Geospatial and Statistical Data Center. Historical Census Browser. (accessed November 8, 2015). http://mapserver.lib.virginia.edu.

United States Department of Treasury, Historical Debt Outstanding-Annual, (accessed March 1, 2016), https://www.treasurydirect.gov/govt/reports/pd/histdebt/histdebt.htm.

United Status Bureau of the Census. Table 7: Population of the 100 Largest Cities: 1840. (accessed November 8, 2015), www.census.gov/population/www/documentation/twps0027/tab07.txt.

James M. Mathews, Digest of the Laws of Virginia of a Civil Nature and of A Permanent Character and General Operation: Illustrated by Judicial Decisions to Which are Prefixed the Constitution of the United States ; and the New Bill of Rights, and Constitution of Virginia, Richmond: J.W. Randolph, 1856.

West Virginia Constitutional Convention. William Burdette Mathews. Frances Haney Atwood. Charles Henry Ambler. West Virginia Constitution. West Virginia. Debates And Proceedings of the First Constitutional Convention of West Virginia (1861-1863). Huntington: Gentry Brothers, 1939.

Virginia Convention. Wheeling, Virginia. Journal of the Convention Assembled At Wheeling: On the 11th of June, 1861. Wheeling, 1861.

United States Congress. The Congressional Globe: Containing the Debates and Proceedings of the Third Session of the Thirty-Seventh Congress. Washington D.C. UNT Digital Library. (Accessed January 1, 2016). http://digital.library.unt.edu/ark:/67531/metadc30856.

Virginia. The Debates and proceedings of the Constitutional convention of the state of Virginia, assembled at the city of Richmond, Tuesday, December 3, 1867: being a full and complete report of the debates and proceedings of the convention, together with the reconstruction acts of Congress and 
those supplementary thereto, the order of the commander of the First military district assembling the convention, and the new constitution. Richmond: Virginia Publishing, 1868.

Special Message of the Governor of Virginia transmitting report of the Commission appointed on the public debt. Richmond: 1892.

Acts and Joint Resolutions Passed by the General Assembly of the Commonwealth of the State of Virginia During the Session of 1899-1900, (Richmond: J.H. O'Bannon, Superintendent of Public Printing, 1900).

Office of the Attorney General. Annual Report of the Attorney General to the Governor of Virginia for the year 1905. Richmond: J.H. O’Bannon, Superintendent of Public Printing, 1905.

Office of the Attorney General. Annual Report of the Attorney General to the Governor of Virginia for the year 1912. Richmond: Davis Bottom, Superintendent of Public Printing, 1913.

Office of the Attorney General. Annual Report of the Attorney General to the Governor of Virginia for the year 1913. Richmond: Davis Bottom, Superintendent of Public Printing, 1914.

Commonwealth of Virginia v. State of West Virginia, Original, No. 7 (1906)

Commonwealth of Virginia v. State of West Virginia, 220 U.S. 1 (1911).

Commonwealth of Virginia v. State of West Virginia, 234 U.S. 117 (1914).

Commonwealth of Virginia v. State of West Virginia, 246 U. S. 565 (1918).

\section{$\underline{\text { Secondary Sources }}$}

$\underline{\text { Books }}$

Adams, Sean Patrick. Old Dominion, Industrial Commonwealth: Coal, Politics, and Economy in Antebellum America. Baltimore: The Johns Hopkins University Press, 2004.

Balleisen, Edward J. Navigating Failure: Bankruptcy and Commercial Society in Antebellum America. Chapel Hill: University of North Carolina Press, 2001.

Beckert, Sven. The Monied Metropolis: New York City and the Consolidation of the American Bourgeoisie, 1850-1896. Cambridge: Cambridge University Press, 2001.

Blight, David W. Race and Reunion: The Civil War in American Memory. Cambridge: Harvard University Press, 2001.

Bodenhorn, Howard. State Banking in Early America: A New Economic History. Oxford: Oxford University Press, 2003. 
Cohen, Nancy. Reconstruction of American Liberalism, 1865-1914. Chapel Hill: University of North Carolina Press, 2002.

Edwards, Laura F. A Legal History of the Civil War and Reconstruction: A Nation of Rights. Cambridge: Cambridge University Press, 2015.

Faust, Drew Gilpin. This Republic of Suffering: Death and the American Civil War. New York: Vintage Books, 2008.

Freehling, William W. and Simpson, Craig M. Showdown in Virginia: The 1861 Convention and the Fate of the Union. Charlottesville: University of Virginia Press, 2010.

Graber, David. Debt: The First 5000 Years. Brooklyn: Melville House, 2011.

Gruenwald, Kim M. River of Enterprise: The Commercial Origins of Regional Identity in the Ohio River Valley, 1790-1850. Bloomington: Indiana University Press, 2002.

Kuttner, Robert. Debtors' Prison: The Politics of Austerity Versus Possibility New York: Alfred A. Knopf, 2013.

Larson, John L. Internal Improvement. Chapel Hill: University of North Carolina Press, 2001.

Lepler, Jessica M. The Many Panics of 1837: People, Politics, and the Creation of a Transatlantic Financial Crisis. Cambridge University Press: Cambridge, 2013.

Lewis, Virgil Anson. History of West Virginia: In Two Parts. Philadelphia: Hubbard Brothers. 1889.

Link, William A. Roots of Secession: Slavery and Politics in Antebellum Virginia. Chapel Hill: University of North Carolina Press, 2003.

Majewski, John. A House Dividing: Economic Development in Pennsylvania and Virginia Before the Civil War. Cambridge: Cambridge University Press, 2000.

Mann, Bruce H. Republic of Debtors: Bankruptcy in the Age of American Independence. Cambridge: Harvard University Press, 2002.

McCraw, Thomas K. The Founders and Finance: How Hamilton, Gallatin, and Other Immigrants Forged a New Economy. Cambridge: Harvard University Press, 2012.

Murphy, Brian Phillips. Building The Empire State: Political Economy in the Early Republic Philadelphia: University of Pennsylvania Press, 2015.

Newton, J.H., Nichols, G.G., and Sprinkle, A.G. History of the Pan-handle; Being Historical Collections of the Counties of Ohio, Brooke, Marshall, and Hancock, West Virginia. Wheeling: J.A. Caldwell, 1879. 
Pearson, Charles Chilton. The Readjuster Movement in Virginia. New Haven: Yale University Press, 1917.

Rice, Otis K. West Virginia: A History. Lexington: University Press of Kentucky, 1985.

Robertson, James Barr. The Confederate Debt and Private Southern Payments (London: Waterlow and Sons, Limited: 1884).

Sandage, Scott. Born Losers: A History of Failure in America. Cambridge: Harvard University Press, 2005.

Schweikart, Larry. Banking in the American South: From the Age of Jackson to Reconstruction. Baton Rouge: Louisiana State University Press, 1987.

Scott, James Brown. Judicial Settlement of Controversies between States of the American Union: An Analysis of Cases Decided in the Supreme Court. New Jersey: Lawbook Exchange: 1919.

Silkenat, David. Moments of Despair: Suicide, Divorce, and Debt in Civil War Era North Carolina. Chapel Hill: University of North Carolina Press, 2011.

Slaughter, Thomas P. The Whiskey Rebellion: Frontier Epilogue to American Revolution. Oxford: Oxford University Press, 1986.

Starnes, George T. Sixty Years of Branch Banking in Virginia. New York: Macmillan Company, 1931.

Stealey III, John E. West Virginia's Civil War-Era Constitution: Loyal Revolution, Confederate Counter-Revolution, and the Convention of 1872. Kent: Kent State University Press, 2013.

Williams, John Alexander. West Virginia and the Captains of Industry. Morgantown: West Virginia University Press, 2003.

Yokota, Karianne Akemi. Unbecoming British: How Revolutionary America Became a Postcolonial Nation. Oxford: Oxford University Press, 2011.

Zimmerman, Joseph F. Interstate Disputes: The Supreme Court's Original Jurisdiction. Ithaca: State University of New York Press, 2006.

$\underline{\text { Journal Articles }}$

Bearss, Sara B. "Restored and Vindicated: The Virginia Constitutional Convention of 1864.” Virginia Magazine of History and Biography 122, no. 2, (March 2014):156-181.

Brown, Henry Billings. "Interstate Controversies in the Supreme Court of the United States.” The 
Advocate of Peace (1894-1920),73, no. 1 (January 1911): 19-20, 30-34.

Carstens,Anne-Marie C. "Lurking in the Shadows of Judicial Process: Special Masters in the Supreme Court’s Original Jurisdictions Cases.” Minnesota Law Review 86, no. 3 (February 2002): 625-629.

Curtis, Christopher M. "Reconsidering Suffrage Reform in the 1829-1830 Virginia Constitutional Convention.” Journal of Southern History, 74, no. 1 (February 2008): 89-124.

Majewski, John. "The Political Impact of Great Commercial Cities: State Investment in Antebellum Pennsylvania and Virginia.” Journal of Interdisciplinary History 28,no. 1 (July 1997): 1-26.

Raitz, Karl and O’Malley, Nancy. “Local-scale turnpike roads in nineteenth-century Kentucky.” Journal of Historical Geography 33, no. 1 (2007): 1-23.

Randall, James G. “The Virginia Debt Controversy.” Political Science Quarterly 30, no. 4 (December 1915): 553-577.

Page, Roswell. “The West Virginia Debt Settlement.” The Virginia Law Register 5, no. 4 (August 1919): 257-283.

Schragger, Richard. “Democracy and Debt.” The Yale Law Journal 121, no. 4 (January 2012): 860868.

Shepard, E. Lee. “ This Being Court Day.” The Virginia Magazine of History and Biography 103, no. 4 (October, 1995): 459-470.

Stealey III, John Edmund. "West Virginia's Constitutional Critique of Virginia: The Revolution of 1861-1863.” Civil War History 57, no. 1 ( March 2011): 9-47.

Harrison, Randolph. “West Virginia’s Contributive Share of the Debt of Virginia.” Virginia Law Register 10, no. 12 (April 1905): 1055-1071.

"States: Adjustment of Public Debt between Virginia and West Virginia." Michigan Law Review 9, no.7 (May, 1911): 626-627.

"Repudiation and State Sovereignty." The Independent ...Devoted to the Consideration of Politics, Social and Economic Tendencies, History, Literature, and the Arts (1848-1921), Aug 13, 1885. (Accessed March 1, 2016) http://search.proquest.com/docview/90424307?accountid=2837.

$\underline{\text { Dissertations }}$

Gillam, George Harrison. (2013) Building a Modern South: Political Economy in Nineteenth Century Virginia (Doctoral Dissertation) Retrieved from ProQuest Dissertation and Thesis (Accession Order No. AAT 3570386). 